\title{
Social Support and its Relationship to Emotional
} Reassurance and Pathological Concerns of Covid-19: A Comparative Study of the Arab and Western

\section{Environments}

\section{Dr. Zaheda Jameel Abu-Aisheh}

Associate Professor of Psychology / Deanship of Supportive Studies / Taif University

\section{Abstract:}

The current research aimed to identify the
effect of social support on emotional
reassurance and pathological concerns of Covid-19 among both the Arab and western environments. and to study the difference between the two environments on the research variables as well as other secondary variables. The sample comprised (300) participants. of whom (173) were from the Arab countries (Palestine. Saudi Arabia. Egypt). and (127) were from some western countries (Canada. France. Germany). To achieve the research aims. three instruments were utilized. namely a researcher-made scale for psychological support and a researcher-made scale for emotional reassurance. in addition to a questionnaire for pathological concerns of Covid-19. Findings confirmed the existence of a high level of social support and emotional reassurance among the samples of the two environments; however. their levels were higher among the Arab environment more than among the western one. as well as the existence of an average level of pathological concerns among the Arab environment sample; however. their levels were higher among the western one. Furthermore. it was found that there is a positive direct relationship between social support and emotional reassurance among the two environments. which is of high level among the western environment sample than among the Arab environment sample. Likewise. a positive direct relationship between social support and pathological concerns among the western environment sample was found; whereas. there was no such relationship among the Arab environment sample. as well as it was found that social support contributed to the prediction of emotional reassurance among the two environments; 
however. it was higher among the western environment sample. On the other hand. social support did not contribute to predicting pathological concerns among the Arab environment; while. it contributed to predicting pathological concerns among the western one.

Key words: Social support. emotional reassurance. pathological concerns. Covid- 19. Arab environment. western environment.

\section{Introduction}

The coronavirus (Covid-19) has infected some individuals in China. specifically in Wuhan Province. and its symptoms began to show to the world that it is a fatal epidemic. Therefore. China officially declared it on 1/11/2020. and the World Health Organization characterized it as a pandemic on 3/11/2020. due to its transmission among countries of the world at a rapid rate. the danger that characterized it. especially its transmission from one individual to hundreds. and the number of deaths caused by it. A worldwide controversy arose over the interpretation of its causes and treatment. but people took precautionary and medical measures. and among the measures taken was the home quarantine that imposed social isolation on millions (Abu-Aisha. 2020).

All peoples are still suffering from this pandemic. millions have been infected. and hundreds of thousands have died because of it. According to the BBC News. the number of infections in the world till the date of this research on (7/18/2020) reached (14270517); while the number of deaths reached (602507). That is why Covid-19 causes negative effects on individuals. whether those who are infected. their relatives and friends. or those who survived the infection. This made everyone realize the value and importance of social support. which they did not have 
directly due to the social isolation imposed on them to limit the spread of the pandemic.

It is certain that the individual cannot live alone in isolation from others all the time. With others. the individual feel belonging. familiarity and reassurance. and can face the different situations with strength and stability. One's behaviors. dreams. imaginations. and habits are affected by others (Duckitt. 2000). Social support is the main effective source that impacts the lives of individuals. which satisfies their need to feel psychological security. lowers the level of their suffering from the stressful events and difficult situations facing them. and relieves symptoms. such as anxiety and depression. (Ali. 2000).

Emotional reassurance plays a significant role in freeing the individual from psychological illnesses. pains. and conflicts. so many scientists consider it an important indicator of mental health. Maslow believes that the main cause of mental illness is the failure to satisfy basic needs. such as physiological needs. safety. love. appreciation. and self-actualization (Odeh. 2002). The emotional reassurance of individuals was affected during the spread of Covid-19. as a result of the suffering they experienced during home quarantine. due to their inability to practice their lives normally. and to communicate with others as they were before the spread of the pandemic. in addition to the pathological concerns that dominated many of them lest they get infected with the virus (Covid-19) from others they met or even were in the same place with them.

These pathological concerns may be normal if they do not control the overall thinking of individuals; however. if such pathological concerns are not controlled. they prevent 
individuals from enjoying their normal life. become an obsession for them at all times. and will have negative effects on their current and future life. Therefore. people during the continuity of Covid-19 existence remain in urgent need to improve their mood. increase their confidence in the beauty of life. and strengthen their sense of safety. in order to achieve their psychological. emotional and social harmony.

The researcher has been interested in studying the relationships between the research variables. in order to participate even with a small part in the prevention and psychological treatment of individuals who have lived during the Covid-19 pandemic.

\section{Research problem}

Countries have taken many decisions since the outbreak of Covid- 19 that led to an almost complete cessation of life in some countries. as they included the closure of most institutions and commercial centers. and the imposition of home quarantine on millions all over the world. This made individuals suffer from loneliness and social isolation. in addition to the missing social support which they were enjoying before the Covid-19 outbreak (Abu-Aisha. 2020).

Social support. represented in giving information and advice on how to face pressures and threats. plays a fundamental role in having good physical and mental health. and in reducing the feeling of helplessness. Besides. it enhances the patient's desire for healing. and increases their self-awareness and acceptance of illness (Othman. 2001). through conveying the feeling that they are not alone in the face of pressures and threats. in addition to the feeling that they are cared for and appreciated. As the more 
individuals receive the support of others. especially those close to them. the less exposure to diseases will be.

This is confirmed by Alferi et al. (2001) and Ballavia (2002) that social support is one of the most important treatment patterns that patients with cancerous tumors need. whether from spouses or friends (Shuwaikh. 2007). Hageoom et al (2000) also found that engaging in dialogues with cancer patients about their disease and discussing them in the best way to solve their problems was very beneficial; while patients' isolation. distancing from others. and absence of interaction with them increased their anxiety as well as fear (Taylor. 2016).

The researcher views that the difficult period the world is going through now in light of the spread of the Covid-19 pandemic along with the decline of direct social contact with others made individuals realize their need for social support because of its positive impact on improving moods. and helping them get out of the cycle of negative thinking in this pandemic. and ending grief over the loss of those whom individuals know. This bad mood and grief may affect their emotional reassurance and their sense of safety. Besides. they may feel that they are in danger and that they may be infected at any moment with this pandemic.

The problem of the current research lies in comparing the relationship between social support and emotional reassurance. as well as between social support and pathological concerns of individuals during Covid-19 pandemic among the Arab environment represented in (Palestine. Saudi Arabia. Egypt) and among the western environment represented in (Canada. France. Germany). 


\section{Research questions}

1. What is the level of social support with its two dimensions (family and community) during Covid-19 among the Arab environment sample?

2. What is the level of social support with its two dimensions (family and community) during Covid-19 among the western environment sample?

3. What is the level of emotional reassurance with its dimensions during Covid-19 among the Arab environment sample?

4. What is the level of emotional reassurance with its dimensions during Covid-19 among the western environment sample?

5. What is the level of pathological concerns during Covid19 among the Arab environment sample?

6 . What is the level of pathological concerns during Covid19 among the western environment sample?

7. Is there a statistically significant correlation between social support with its two dimensions (family and community) and emotional reassurance with its dimensions during Covid-19 among the Arab environment sample?

8. Is there a statistically significant correlational between social support with its two dimensions (family and community). and emotional reassurance with its dimensions during Covid-19 among the western environment sample?

9. Is there a statistically significant correlational between social support with its two dimensions (family and community) and pathological concerns during Covid-19 among the Arab environment sample?

10. Is there a statistically significant correlational between social support with its two dimensions (family and 
community) and pathological concerns during Covid-19 among the western environment sample?

11. Does social support contribute to predicting emotional reassurance during Covid-19 among the Arab environment sample?

12. Does social support contribute to predicting emotional reassurance during Covid-19 among the western environment sample?

13. Does social support contribute to predicting pathological concerns during Covid-19 among the Arab environment sample?

14. Does social support contribute to predicting pathological concerns during Covid-19 among the western environment sample?

15. Are there statistically significant differences with respect to the nationality variable (Arab environment sample and western environment sample) in social support with its two dimensions (family and community) during Covid-19?

16. Are there statistically significant differences with respect to the nationality variable (Arab environment sample and western environment sample) on emotional reassurance with its dimensions during Covid-19?

17. Are there statistically significant differences with respect to the nationality variable (Arab environment sample and western environment sample) on pathological concerns during Covid-19?

\section{Research aims}

The current research aimed to identify:

1. The level of social support with its two dimensions (family and community) during Covid-19 among the Arab environment sample and western environment sample. 
2. The level of emotional reassurance with its various dimensions during Covid-19 among the Arab environment sample and western environment sample.

3. The level of pathological concerns during Covid-19 among the Arab environment sample and western environment sample.

4. The correlation between social support and emotional reassurance during Covid-19 among the Arab environment sample and western environment sample.

5. The correlation between social support and pathological concerns during Covid-19 among the Arab environment sample and western environment sample.

6. The contribution of social support to predicting emotional reassurance during Covid-19 among the Arab environment sample and western environment sample.

7. The contribution of social support to predicting pathological concerns during Covid-19 among the Arab environment sample and western environment sample.

8. The differences between the mean scores of the Arab environment sample and western environment sample on social support during Covid-19.

9. The differences between the mean scores of the Arab environment sample and western environment sample on emotional reassurance during Covid-19.

10. The differences between the mean scores of the Arab environment sample and western environment sample on pathological concerns during Covid-19.

\section{Research significance}

\section{A) Theoretical significance:}

- This research is considered the first of its kind that compares the Arab and western environments with regard to the Covid-19 pandemic in terms of social support and its 
relationship to emotional reassurance and pathological concerns of Covid-19.

- This research deals with psychosocial variables that concern all individuals who felt their value during the Covid-19 pandemic.

- Many respondents (in the countries to which the research was applied) expressed their eagerness to know the findings of this research. as it affects an important aspect of their personal and psychological lives.

\section{B) Practical significance:}

- The current research contains scientific information and analyses of great value in the psychological lives of individuals. which may have positive effects on individuals and decision-makers.

- Relationships between the variables of this research may play a significant role in the prevention or even in the psychological treatment of individuals who have suffered from the Covid-19 pandemic. whether these individuals help themselves. or they are provided with assistance through psychological counseling institutions.

-The findings of this research may be suitable for use by researchers and those interested in emergency and dangerous situations which are similar to Covid-19.

- Raising the social institutions' and psychological counseling centers' awareness of the importance of social support in changing the lives of individuals for the better and in achieving emotional reassurance for them.

- Enriching the Arab library and researchers with a research topic that is the first of its kind. with its variables. aims and findings.

\section{Research delimitations \& boundaries}

Aim: the research was delimited to studying social support and its relationship to emotional reassurance and 
pathological concerns of Covid-19. comparing the findings of both the Arab and western research samples.

Place of study: the Arab environment (Palestine. Saudi Arabia. Egypt). and the western environment (Canada. France. Germany).

Time of study: the months of May. June and July of the year 2020 (during the outbreak of the Covid -19 pandemic).

Sample/participants: a sample of residents in Arab countries (Palestine. Saudi Arabia. Egypt). and a sample of residents in western countries (Canada. France. Germany).

\section{Research terms \& definitions}

1) Social support: It is the psychological. spiritual. social and tangible assistance provided to the individual by others or vice-versa. which contributes to facilitating meeting life's needs and achieving psychological and social harmony. (Christyn. et al. 2000)

The researcher defines it as the incorporeal. psychological. tangible and practical assistance provided to the individual (who accepts it) in all stages of their life and in all situations and events they live. which gives confidence and increases life appreciation for themselves and others. This assistance is provided through two important sources: the family and community represented in the surrounding environment. the study environment. friends and colleagues.

The researcher operationally defines it as the various aids and assistance that the individual gets from others during Covid-19. which change their life. and give an intrinsic strength that makes them able to overcome the feeling of 
fear. despair. frustration and isolation. It is measured through the scores that the respondent gets on the scale.

2) Emotional reassurance: It is the individual's feeling that they are loved. respected. and accepted by others. who are able to provide help and protection when exposed to dangers in any situation. especially those by those who are close. such as parents and siblings. Thus. emotional reassurance means the individual's feeling that they are not alone when exposed to crises (Kerns. et al. 2001).

The researcher operationally defines it as a sense of safety. psychological comfort. satisfaction and conviction and that the course of life is going well and positively. It is measured through the scores that the respondent gets on the scale.

3) Pathological concerns: They are persistent and irrational fears of specific things. (which the individual knows that they are unreasonable most of the time). with a desire to avoid these fear-provoking things. because their existence causes severe distress and tension. and in many cases. it is accompanied by physical symptoms. Such pathological concerns affect the individual's psychological stability. (Gelder. 2012)

The researcher operationally defines it as the unreal thoughts and obsessions that control individuals as a result of the existence of stimuli around them which push them to think of; e.g. the spread of the Covid-19 pandemic. It is measured by scores obtained by the respondent on the questionnaire.

4) Covid 19 (Corona): A viral epidemic that struck the world at the beginning of 2020. starting with China and moving to the countries of the world. causing panic 
between countries and individuals due to the rapid acceleration of the numbers infected with every minute. which made the World Health Organization call it pandemic (Abu-Aisha. 2020).

\section{Theoretical framework}

\section{First: Social support:}

Allah. the almighty. said "Worship Allah and associate nothing with Him. and to parents do good. and to relatives. orphans. the needy. the near neighbor. the neighbor farther away. the companion at your side. the traveler. and those whom your right hands possess. Indeed. Allah does not like those who are self-deluding and boastful" (36. An-Nisaa).

\section{Nu'man b. Bashir reported Allah's Messenger (may} peace be upon him) as saying: "The similitude of believers in regard to mutual love. affection. fellow-feeling is that of one body; when any limb of it aches. the wholebody aches. because of sleeplessness and fever." (Sahih Bukhari).

There is no doubt that the individual is in dire need of social relations. as they provide social support that makes them feel strength as an individual in a group. they provide protection from the negative effects of the dangers that may threaten them. and gives psychological security and emotional support. The importance of social support becomes evident in difficult situations that lead the individual to be subject to psychological stress/pressures which make them feel that their energy has been exhausted. they are unable to face crises and threats alone. as well as they need someone to help them overcome the crises and pressures. 
Social support help the individual rid of the negative behavior by giving them the strength to face the difficult and harsh life events. and it has a strong impact if it comes from close people. from social relations dominated by feelings of love and trust. and from their belief in the presence of close people whom they can trust. and who can take care of and stand by in times of crises. Hence. this support becomes protective barriers for the individual from the negative health effects that may accompany any crises. so that it mitigates their effects. and sometimes get rid of them. allowing the individual to achieve psychological and social harmony. (Al-Madhoun. 2004; Fayed. 2005 \& Harel et al. 2012).

\section{Types of social support:}

1. Emotional support: through a feeling of comfort and acceptance.

2. Tangible support: by providing physical services to the individual.

3. Behavioral support: through participating in the performance of deeds.

4. Informational support: by giving information or skills.

5. Appraisal support: by passing on information that helps in evaluating performance.

6. Companionship support: through the assistance and support provided to the individual by others.

7. Esteem support: through moral and self-help support to overcome obstacles and problems. (Radwan. 2001; AlOtaibi. 2008 \& Al-Khashab. 2002)

\section{Social Support Sources:}

Taylor (2011) states that social support comes from several sources. such as family. friends. social relations. and coworkers. The current research focused on two main sources 
of social support: family and community. due to their importance in the life of the individual. and their great influence on the details of the situations and crises that they are exposed to in life.

\section{Second: Emotional reassurance:}

It is a relative feeling of comfort and tranquility. which varies from one person to another. and which appears in the individual's sense of liberation from tension as well as satisfaction. as a result of meeting their personal. physical. psychological and social needs. such as the need for selfactualization and social appreciation. and as a result of the achievements they have achieved. This makes the individual feel comfortable and calm. love themselves and others. not afraid to face sudden situations. accept life. and make efforts to achieve their goals (Ibrahim. 2010 \& Odeh. 2002).

Emotional reassurance is considered as one of the basic needs for building a healthy personality at all stages of life. starting from childhood until the end of the individual's life. If the individual is exposed to psychological or social pressures that cannot be overcome. this tranquility becomes threatened. which makes them psychologically disturbed (Al-Dulaim. 2005).

The individual resorts to achieving emotional reassurance through enhancing self-confidence. identifying strengths and weaknesses. working to satisfy primary needs. exploiting capabilities positively. distinguishing the reality in which they live. appreciating others and earning others' love and respect (Al-Shamimary \& Barakat. 2011).

\section{Importance of emotional reassurance:}

1) Achieving stability: this leads to psychological stability away from disturbance. 
2) Optimism: being away from despair and frustration from life situations.

3) Integration of the human personality: this makes the individual calm in all aspects of life. optimistic and confident of themselves and their abilities. (Sharif. 2003).

The researcher emphasizes the main role of the environment surrounding the individual in achieving emotional reassurance for themselves. especially when exposed to urgent events as happened and is still happening during Covid-19 pandemic. This can be done through dealing transparently and providing correct information from reliable sources. which many countries have been alerted to. They published the correct information and infected cases through direct press conferences. which allows the individual to clearly know and evaluate the course of affairs. and to face reality firmly and consistently.

\section{Third: Pathological concerns:}

Pathological concerns include a severe and irrational degree of fear and dread. which severely affects the behavior of the individual. Such pathological concerns appear as a result of responses to stimuli already present in the environment around (Saad. 2001).

There is no doubt that individuals are still living a difficult experience during the outbreak of the Covid-19 pandemic in most countries of the world. and many of them suffered from pathological concerns while practicing life habits. The idea of getting infected by others may have controlled some individuals as a result of the rapid transmission of the virus from one person to others. The level of these pathological concerns differs from one person to another 
according to the level of faith in God (Allah. Almighty) and in destiny and Divine Decree. as well as according to the accurate information about this virus and the methods of its spread. some of which are still not understood thus far.

\section{Pathological concerns are divided into three sections:}

1) Simple phobia: it is an intense. persistent and irrational fear that is accompanied by anxiety due to something specific. such as fear of animals. heights. plane. disease and death. It is diagnosed in the individual if it hinders them from normal life or obstructs their relationships with others.

2) Social phobia: it is a psychological disorder represented by severe anxiety when exposed to social situations. such as those situations when the individual feels that they are being watched. especially when entering public places. e.g. restaurants.

3) Agoraphobia (Phobia of crowded places): it is the individual's fear of places from which it is difficult to exit. or it is difficult to seek help in the event of a panic (Dukhan \& Al-Hajjar. 2000 \& Abdul-Rahman. 2014).

\section{Previous studies}

After reviewing a great deal of literature (hundreds of studies) related to the current research variables. no single scientific work (to the researcher's best knowledge). that dealt with the three main variables the current research. was found. Likewise. there are no studies concerned with any of the variables conducted during the Covid -19 pandemic. and no comparative studied between the Arab environment and the western environment regarding the Covid-19 pandemic were found. Therefore. the researcher preferred to review some studies relating to some variables 
of the current research. which were conducted prior to the Covid-19 pandemic. These studies will be reviewed from the oldest to the newest as follows:

Kerns et al. (2001) aimed to reveal the psychological reassurance and feeling of psychological loneliness of preteen children. To this aim. a sample consisted of (76) children in the fifth-grade and a scale of reassurance were utilized. It was found that there is a negative correlation between the feeling of reassurance and that of loneliness. and that children who obtained high sores on reassurance were more aware of control and had a positive view towards themselves and others; while. those who got low scores were more anxious and had a negative view of themselves and others.

In addition. the study of Odeh (2002) aimed to identify the level of emotional reassurance and the relationship between it and the psychosocial climate and the strength of the ego. 376 students from the Islamic University participated as a sample. and the measurement instruments included a psychosocial scale. an emotional reassurance scale. as well as a self-esteem scale. Findings revealed the existence of a direct relationship between the psychosocial climate and emotional reassurance among the sample members.

With a sample consisting of (288) students in the first year of King Saud University in Riyadh. Al-Dulaim (2005) aimed to explore the relationship between the feeling of emotional reassurance and the feeling of psychological loneliness. To this aim. a scale of emotional reassurance and a psychological loneliness scale were utilized. The study confirmed the existence of a positive relationship between emotional reassurance and the feeling of loneliness. 
In a similar way. Al-Jabali (2006) conducted a study to reveal the relationship between social support and psychological stress among the students of medicine and health sciences at Sana'a University. A sample comprising (261) participants responded to the social support scale. It was confirmed that the level of social support of the students of the College of Medicine and Health Sciences is high. and that there is no significant relationship between social support and psychological stress among the sample members.

Besides. to explore the relationship between social support and anxiety. Grassi et al. (2007) conducted a study on a sample included (1341) family care workers in Italy. whose ages ranged between (18-80 years). The social support questionnaire and anxiety questionnaire were used. The study confirmed that individuals who received less support scored higher on the dimensions of anxiety. depression. sadness. and pathological concerns. and that mental illness prevailed among them compared with those who received greater support.

Abu Talib (2011) conducted a study aimed to identify the level of social support and psychological security. and to reveal the relationship between them. The sample consisted of (4000) students. divided into two equal groups (displaced and non-displaced from secondary schools in Jazan region). The researcher used the two scales of social support and psychological security as instruments for this study. It was revealed that the level of social support is average among the members of the two groups. and that the government support dimension came first. followed by the family support dimension. In addition. a negative inverse correlation was found between the total score of 
social support and psychological security of members of the two groups.

\section{Commentary on previous studies}

After reviewing the previous studies. we find that some of them explored social support and its relationship to some variables. such as psychological stress. psychological anxiety. psychological security; whereas. others dealt with emotional reassurance and its relationship to psychological loneliness and the psycho-social climate. As for pathological concerns as a result of epidemics. the researchers focused on articles. Samples (participants). measurement scales. and statistical treatments varied from one study to another. The researcher benefited from these studies in the theoretical framework. statistical treatments. and discussion of the current research findings.

\section{Research procedures}

\section{First: Research methodology:}

The researcher adopted the comparative descriptive research method because it is the most appropriate for the current research variables.

\section{Second: Research population and Sample:}

Research population: The research population consisted of residents in some Arab countries (Palestine. Saudi Arabia. Egypt). and residents in some western countries (Canada. France. Germany). during the months of May. June and July of the year 2020.

Research sample: The sample included randomly selected (300) respondents from (Palestine. Saudi Arabia. Egypt). and from (Canada. France. Germany). during the months of May. June and July of the year 2020. The following tables explain the characteristics of this sample in detail: 
Table (1): Distribution of the sample according to the age group $(\mathbf{n}=\mathbf{3 0 0})$

\begin{tabular}{|c|c|c|}
\hline Age Group & Number of Respondents & Percentage \\
\hline $18-25$ & 105 & $35.0 \%$ \\
\hline $26-33$ & 58 & $19.33 \%$ \\
\hline $34-41$ & 50 & $16.66 \%$ \\
\hline $42-49$ & 87 & $29.0 \%$ \\
\hline Total & $\mathbf{3 0 0}$ & $\mathbf{1 0 0 \%}$ \\
\hline
\end{tabular}

Table (2): Distribution of the sample according to academic qualification $(\mathbf{n}=\mathbf{3 0 0})$

\begin{tabular}{|c|c|c|}
\hline $\begin{array}{c}\text { Academic } \\
\text { Qualification }\end{array}$ & Number of Respondents & Percentage \\
\hline $\begin{array}{c}\text { Pre-university } \\
\text { degree }\end{array}$ & 52 & $17.3 \%$ \\
\hline Bachelor & 194 & $64.7 \%$ \\
\hline Master & 21 & $7.0 \%$ \\
\hline Doctorate/ Ph.D. & 33 & $11.0 \%$ \\
\hline Total & 300 & $100 \%$ \\
\hline
\end{tabular}

Table (3) Distribution of sample members according to type of work $(n=300)$

\begin{tabular}{|c|c|c|}
\hline Type of work & $\begin{array}{c}\text { Number of } \\
\text { Respondents }\end{array}$ & Percentage \\
\hline Student & 82 & $27.3 \%$ \\
\hline Government sector employee & 54 & $18.0 \%$ \\
\hline Private sector employee & 71 & $23.7 \%$ \\
\hline Free business & 93 & $31.0 \%$ \\
\hline Total & 300 & $100 \%$ \\
\hline
\end{tabular}

\section{Descriptive statistics of the two research samples on} research variables:

To verify that the research sample's scores are normally distributed on the research variables. the means. standard deviations. medians. mode. and skewness coefficients were calculated for the main study sample (Arab environment sample and western environment sample). and the results were as shown in the following table:

Table (4) shows the following:

1) All values of the mean are higher than standard deviations. and that the skewness values are close to zero. 
in addition to the close values of the mean and median of both samples. which indicates the small size of the variance between the respondents 'scores on research variables and that the variables' scores are close to the normal distribution of the two research samples.

Table (4): Descriptive statistics of the research sample on research variables $(\mathbf{n}=300)$

\begin{tabular}{|c|c|c|c|c|c|c|}
\hline \multirow{2}{*}{\multicolumn{2}{|c|}{ Variables }} & \multicolumn{5}{|c|}{ Descriptive statistics } \\
\hline & & \multirow{2}{*}{$\begin{array}{r}\text { Mean } \\
33.89\end{array}$} & \multirow{2}{*}{$\begin{array}{c}\text { Median } \\
\mathbf{3 5 . 0 0}\end{array}$} & \multirow{2}{*}{$\begin{array}{l}\text { Mode } \\
40.00\end{array}$} & \multirow{2}{*}{$\begin{array}{r}\text { Standard } \\
\text { Deviation }\end{array}$} & \multirow{2}{*}{$\begin{array}{r}\text { Skewness } \\
-0.915\end{array}$} \\
\hline \multirow{8}{*}{$\begin{array}{c}\text { Arab } \\
\text { environment } \\
\text { sample }=173\end{array}$} & Family support & & & & & \\
\hline & Community support & 24.35 & 25.00 & 26.00 & 4.05 & -0.560 \\
\hline & $\begin{array}{c}\text { Social supports as a } \\
\text { whole }\end{array}$ & 58.24 & 59.00 & 66.00 & 8.17 & -0.716 \\
\hline & Emotional maturity & 15.97 & 16.00 & 20.00 & 2.88 & -0.289 \\
\hline & Self-satisfaction & 24.18 & 24.00 & 26.00 & 3.88 & -0.439 \\
\hline & $\begin{array}{c}\text { Optimism about the } \\
\text { future }\end{array}$ & 12.18 & 13.00 & 15.00 & 2.60 & -1.00 \\
\hline & $\begin{array}{c}\text { Emotional } \\
\text { reassurance as a } \\
\text { whole } \\
\end{array}$ & 52.34 & 53.00 & 53.00 & 8.16 & -0.414 \\
\hline & $\begin{array}{c}\text { Pathological } \\
\text { concerns }\end{array}$ & 27.87 & 28.00 & 27.00 & 8.55 & -0.208 \\
\hline \multirow{8}{*}{$\begin{array}{c}\text { western } \\
\text { environment } \\
=\mathbf{1 2 7} \\
\text { sample=127 }\end{array}$} & Family support & 29.75 & 29.00 & 40.00 & 7.69 & -0.184 \\
\hline & Community support & 23.34 & 23.00 & 30.00 & 4.91 & -0.022 \\
\hline & $\begin{array}{c}\text { Social supports as a } \\
\text { whole }\end{array}$ & 53.10 & 56.00 & 70.00 & 11.82 & - 0.004 \\
\hline & Emotional maturity & 14.84 & 15.00 & 12.00 & 3.81 & 0.172 \\
\hline & Self-satisfaction & 23.03 & 24.00 & 27.00 & 4.84 & -0.704 \\
\hline & $\begin{array}{c}\text { Optimism about the } \\
\text { future }\end{array}$ & 11.74 & 13.00 & 15.00 & 3.48 & -0.861 \\
\hline & $\begin{array}{c}\text { Emotional } \\
\text { reassurance as a } \\
\text { whole } \\
\end{array}$ & 49.62 & 51.00 & 54.00 & 10.79 & -0.578 \\
\hline & $\begin{array}{c}\begin{array}{c}\text { Pathological } \\
\text { concerns }\end{array} \\
\end{array}$ & 36.25 & 38.00 & 43.00 & 8.28 & -1.00 \\
\hline
\end{tabular}

2) The mean of the Arab environment sample on the social support variable is higher than the mean of the western environment sample.

3) The mean of the Arab environment sample on the emotional reassurance variable is higher than the mean of the western environment sample.

4) The mean of the western environment sample on the pathological concerns variable is higher than the mean of the Arab environment sample. 


\section{Third: Research instruments}

The researcher developed the two scales of social support and emotional reassurance. in addition to a questionnaire for pathological concerns to be the research instruments.

First: Social Support Scale: The researcher reviewed many studies that focused on social support. and preferred to design a social support scale that included (14) items distributed into two main dimensions: family and community. When scoring. it was taken into account the existence of four negative items.

Psychometric properties of the scale of social support:

1) Validity of the scale: The researcher verified the validity of the scale of social support by:

A) Face validity (Jury members validity): The scale was submitted to a panel of (10) jury members (professors) specialized in the field of education and psychology. in order to judge the face validity of the dimensions and items in terms of their suitability for social support. and their agreement on the dimensions and items ranged between $(89-92 \%)$.

B) Internal consistency validity: The internal consistency of the social support scale and its two dimensions (family and community) was calculated as an indicator of the integrity of the scale structure. by using the Pearson correlation coefficient to exclude the items that do not correlate significantly to the score on the dimension to which they belong. Then. the correlation coefficient between the scores of the dimension and the scale as a whole was calculated as shown in table (5):

Finding the correlation coefficient between items score and the score of the dimension to which they belong: It is evident from Table (5) that significant correlations have been found between the two dimensions and the total score of the scale. all of which are at the level of (0.01). Hence. these results indicate that the scale has a great deal 
of internal homogeneity of the items and the two dimensions.

Table (5): Correlation coefficients between item score and the score of the dimension to which it belongs $(n=100)$

\begin{tabular}{|c|c|c|c|c|c|}
\hline $\begin{array}{c}\text { Item } \\
\text { Number }\end{array}$ & Dimension & $\begin{array}{c}\text { Correlation } \\
\text { coefficient }\end{array}$ & $\begin{array}{c}\text { Item } \\
\text { Number }\end{array}$ & Dimension & $\begin{array}{c}\text { Correlation } \\
\text { coefficient }\end{array}$ \\
\hline 1 & \multirow{8}{*}{$\begin{array}{l}\text { Family } \\
\text { Support }\end{array}$} & $0.691 * *$ & 9 & \multirow{8}{*}{$\begin{array}{c}\text { Community } \\
\text { Support }\end{array}$} & $0.466 * *$ \\
\hline 2 & & $0.655 * *$ & 10 & & $0.516 * *$ \\
\hline 3 & & $0.758 * *$ & 11 & & $0.571 * *$ \\
\hline 4 & & 0.726 *** & 12 & & $0.640 * *$ \\
\hline 5 & & $0.566 * *$ & 13 & & $\mathbf{0 . 4 3 0} * *$ \\
\hline 6 & & $0.682 * *$ & 14 & & $0.398 * *$ \\
\hline 7 & & $0.672 * *$ & & & \\
\hline 8 & & $\mathbf{0 . 5 0 0}$ ** & & & \\
\hline
\end{tabular}

** All values are significant at $(0.01)$ level.

C) Discriminant validity: Discriminant validity was verified for each item of the social support scale with its two dimensions through calculating the highest and lowest quartiles of the piloting sample. and then the t-test was used for each item to verify that the item is able to distinguish between the highest group and the lowest group of the piloting sample on the two dimensions of social support. Table (6) shows the results of discriminant validity:

As shown in Table (6). all the values of t-test are significant at the level of (0.01) for all items. which indicates that all items are able to distinguish between the lowest and highest quartiles on the social support scale with its two dimensions (family and community). and this indicates discriminant validity as well as its suitability for use.

2) Reliability of the scale: The reliability of the social support scale was established by the Cronbach's Alpha coefficient for the two dimensions of the scale and the overall score of the scale. which came as shown in Table (7): 
Table (6) Discriminant validity of the Social Support Scale $(n=100)$

\begin{tabular}{|c|c|c|c|c|c|}
\hline Group & Dimension & $\begin{array}{c}\text { Item } \\
\text { Numbe } \\
\mathbf{r} \\
\end{array}$ & Mean & T-value & Sig. Level \\
\hline Lowest & \multirow{16}{*}{$\begin{array}{l}\text { First dimension } \\
\text { Family Support }\end{array}$} & \multirow[t]{2}{*}{1} & 2.800 & \multirow[t]{2}{*}{9.52} & \multirow[t]{2}{*}{0.00} \\
\hline Highest & & & 5.000 & & \\
\hline Lowest & & \multirow[t]{2}{*}{2} & 3.04 & \multirow[t]{2}{*}{8.07} & \multirow[t]{2}{*}{0.00} \\
\hline Highest & & & 4.96 & & \\
\hline Lowest & & \multirow[t]{2}{*}{3} & 2.44 & \multirow[t]{2}{*}{12.12} & \multirow[t]{2}{*}{0.00} \\
\hline Highest & & & 4.84 & & \\
\hline Lowest & & \multirow[t]{2}{*}{4} & 2.84 & \multirow[t]{2}{*}{8.86} & \multirow[t]{2}{*}{0.00} \\
\hline Highest & & & 4.96 & & \\
\hline Lowest & & \multirow[t]{2}{*}{5} & 3.00 & \multirow[t]{2}{*}{10.06} & \multirow[t]{2}{*}{0.00} \\
\hline Highest & & & 4.92 & & \\
\hline Lowest & & \multirow[t]{2}{*}{6} & 2.68 & \multirow[t]{2}{*}{10.72} & \multirow[t]{2}{*}{0.00} \\
\hline Highest & & & 4.80 & & \\
\hline Lowest & & \multirow[t]{2}{*}{7} & 3.44 & \multirow[t]{2}{*}{7.47} & \multirow[t]{2}{*}{0.00} \\
\hline Highest & & & 5.00 & & \\
\hline Lowest & & \multirow[t]{2}{*}{8} & 3.32 & \multirow[t]{2}{*}{7.24} & \multirow[t]{2}{*}{0.00} \\
\hline Highest & & & 4.92 & & \\
\hline Lowest & \multirow{12}{*}{$\begin{array}{l}\text { Second dimension } \\
\text { Community Support }\end{array}$} & \multirow[t]{2}{*}{9} & 3.28 & \multirow[t]{2}{*}{6.01} & \multirow[t]{2}{*}{0.00} \\
\hline Highest & & & 4.68 & & \\
\hline Lowest & & \multirow[t]{2}{*}{10} & 2.64 & \multirow[t]{2}{*}{12.48} & \multirow[t]{2}{*}{0.00} \\
\hline Highest & & & 4.76 & & \\
\hline Lowest & & 11 & 3.44 & 6.50 & 0.00 \\
\hline Highest & & & 4.76 & & \\
\hline Lowest & & 12 & 2.92 & 9.66 & 0.00 \\
\hline Highest & & & 4.92 & & \\
\hline Lowest & & 13 & 3.00 & 4.79 & 0.00 \\
\hline Highest & & & 4.44 & & \\
\hline Lowest & & 14 & 3.72 & 5.36 & 0.00 \\
\hline Highest & & & 4.96 & & \\
\hline
\end{tabular}

Validity of all items is significant at the (0.01) level.

Table (7): Reliability coefficients of the social support scale with its two dimensions (family and community)

\begin{tabular}{|c|c|c|c|}
\hline No. & Dimensions & Item No. & $\begin{array}{c}\text { Cronbach's } \\
\text { Alpha coefficient }\end{array}$ \\
\hline 1 & Family Support & $\mathbf{8}$ & $\mathbf{0 . 8 8 4}$ \\
\hline $\mathbf{2}$ & Community Support & $\mathbf{6}$ & $\mathbf{0 . 7 3 4}$ \\
\hline \multicolumn{2}{|c|}{ Scale of Social Support as a whole } & $\mathbf{1 4}$ & $\mathbf{0 . 8 9 3}$ \\
\hline
\end{tabular}

It can be seen from Table (7) that all the reliability coefficients of the two dimensions as well as the scale as a 
whole are high. indicating that the scale has a high degree of reliability.

\section{Second: Emotional Reassurance Scale:}

The researcher reviewed many studies that focused on emotional reassurance. and designed a scale for this variable. It included (16) items divided into three main dimensions: emotional maturity. self-satisfaction. and optimism about the future. When establishing the internal consistency validity of the scale. three items were omitted because the value of their correlation with the overall score of the dimension was not significant. thus the number of the final items of the scale is (13). When scoring. it was taken into account the existence of one negative item.

\section{Psychometric properties of the emotional reassurance} scale:

1) Validity of the scale: The researcher verified the validity of the emotional reassurance scale through:

A) Face validity (Jury members validity): The scale was submitted to a panel of (8) jury members (professors) specialized in the field of education and psychology. in order to judge the face validity of the dimensions and items in terms of their suitability for emotional reassurance. and their agreement on the dimensions and items ranged between (85-88\%).

B) Internal consistency validity: The internal consistency of the emotional reassurance scale with its dimensions was calculated as an indicator of the integrity of the scale structure. by using the Pearson correlation coefficient to exclude the items that do not correlate significantly to the overall score of the scale as shown in table (8):

The results of Table (8) indicate that all items have a significant correlation at the level of $(0.01)$ with the overall score of the scale. These items have been agreed on. with 
the exception of the items (3.12.15) which were omitted; as each item of them does not correlate significantly with the overall score of the dimension to which each individual item belongs.

Finding the correlation coefficient between the items score and the dimension score to which they belong:

Table (8): Correlation coefficients between the item score and score of the dimension to which it belongs $(n=100)$

\begin{tabular}{|c|c|c|c|c|c|}
\hline Item No. & Dimension & $\begin{array}{l}\text { Item Correlation } \\
\text { coefficient with scale } \\
\text { overall score }\end{array}$ & $\begin{array}{c}\text { Item } \\
\text { No. }\end{array}$ & Dimension & $\begin{array}{c}\text { Item Correlation } \\
\text { coefficient with scale } \\
\text { overall score }\end{array}$ \\
\hline 1 & \multirow{6}{*}{$\begin{array}{c}\text { Emotio } \\
\text { nal } \\
\text { Maturit } \\
\mathbf{y}\end{array}$} & $0.660^{* *}$ & 6 & \multirow{6}{*}{$\begin{array}{c}\text { Self- } \\
\text { satisfac } \\
\text { tion }\end{array}$} & $0.649 * *$ \\
\hline 2 & & $0.685 * *$ & 7 & & $0.552 * *$ \\
\hline 3 & & 0.122 Not Sig. & 8 & & $0.692 * *$ \\
\hline 4 & & $0.502 *$ & 9 & & $0.395 * *$ \\
\hline \multirow[t]{2}{*}{5} & & $0.693 * *$ & 10 & & $0.540 * *$ \\
\hline & & & 11 & & $0.547 * *$ \\
\hline 12 & \multirow{5}{*}{$\begin{array}{l}\text { Optimi } \\
\text { sm } \\
\text { about } \\
\text { the } \\
\text { future }\end{array}$} & 0.105 Not Sig. & & & \\
\hline 13 & & $0.777 * *$ & & & \\
\hline 14 & & $0.786 * *$ & & & \\
\hline 15 & & 1 ^ • • غير دالة & & & \\
\hline 16 & & $0.605 * *$ & & & \\
\hline
\end{tabular}

All values are significant at level $(0.01)$.

- Finding the correlation coefficient between the score of sub-dimensions and the overall score of the scale as shown in Table (9):

Table (9): Correlation coefficients between the score of subdimensions and the overall score of the scale

\begin{tabular}{|c|c|c|}
\hline No. & Sub-dimensions of the scale & $\begin{array}{c}\text { Correlation with the overall } \\
\text { score of the scale }\end{array}$ \\
\hline 1 & Emotional Maturity & $\mathbf{8 2 9 . 0} * *$ \\
\hline 2 & Self-satisfaction & $\mathbf{9 2 6 . 0} * *$ \\
\hline 3 & Optimism about the future & $\mathbf{8 4 8 . 0} * *$ \\
\hline
\end{tabular}

** All values are significant at ( $(0.01)$ level.

Table (9) clearly shows that significant correlations have been found between each dimension of the scale and the overall score of the scale. all of which are at the level of (0.01). Hence. these results indicate that the scale has a 
great deal of internal homogeneity of the items and dimensions.

C) Discriminant validity: Discriminant validity was verified for each item of the emotional reassurance scale through calculating the highest and lowest quartiles of the piloting sample. and then the t-test was used for each item to verify that the item is able to distinguish between the highest group and the lowest group of the piloting sample on emotional reassurance. Table (10) shows the results of discriminant validity:

It is evident from Table (10) that all the values of the t-test are significant at the level of $(0.01)$. which indicates that all items are able to distinguish between the lowest and highest quartiles on the emotional reassurance scale with its dimensions. and this indicates the discriminant validity of the scale as well as its suitability for use.

Table (10): Discriminant validity of emotional reassurance scale with its various dimensions $(n=100)$

\begin{tabular}{|c|c|c|c|c|c|}
\hline Group & Dimension & $\begin{array}{c}\text { Item } \\
\text { Number }\end{array}$ & Mean & T-value & Sig. Level \\
\hline Lowest & \multirow{8}{*}{$\begin{array}{l}\text { Emotional } \\
\text { Maturity }\end{array}$} & \multirow{2}{*}{1} & 3.16 & \multirow[t]{2}{*}{6.71} & \multirow[b]{2}{*}{0.00} \\
\hline Highest & & & 4.64 & & \\
\hline Lowest & & \multirow{2}{*}{2} & 3.24 & \multirow[t]{2}{*}{8.68} & \multirow[t]{2}{*}{$\overline{0.00}$} \\
\hline Highest & & & 4.96 & & \\
\hline Lowest & & \multirow{2}{*}{3} & 3.200 & \multirow[t]{2}{*}{9.97} & \multirow[t]{2}{*}{0.00} \\
\hline Highest & & & 4.92 & & \\
\hline Lowest & & \multirow{2}{*}{4} & 2.64 & \multirow[t]{2}{*}{13.02} & \multirow[t]{2}{*}{0.00} \\
\hline Highest & & & 4.84 & & \\
\hline Lowest & \multirow{12}{*}{$\begin{array}{c}\text { Self- } \\
\text { satisfaction }\end{array}$} & \multirow{2}{*}{5} & 2.72 & \multirow[t]{2}{*}{12.26} & \multirow[t]{2}{*}{0.00} \\
\hline Highest & & & 4.96 & & \\
\hline Lowest & & \multirow{2}{*}{6} & 3.12 & \multirow[t]{2}{*}{6.30} & \multirow[t]{2}{*}{0.00} \\
\hline Highest & & & 4.80 & & \\
\hline Lowest & & \multirow{2}{*}{7} & 2.84 & \multirow[t]{2}{*}{8.12} & \multirow[t]{2}{*}{0.00} \\
\hline Highest & & & 4.68 & & \\
\hline Lowest & & \multirow[b]{2}{*}{8} & 3.36 & \multirow[t]{2}{*}{4.59} & \multirow[t]{2}{*}{0.00} \\
\hline Highest & & & 4.60 & & \\
\hline Lowest & & \multirow{2}{*}{9} & 3.40 & \multirow[t]{2}{*}{6.81} & \multirow[t]{2}{*}{0.00} \\
\hline Highest & & & 4.92 & & \\
\hline & & \multirow[t]{2}{*}{10} & 2.84 & \multirow[t]{2}{*}{8.133} & \multirow[t]{2}{*}{0.00} \\
\hline & & & 4.52 & & \\
\hline Lowest & \multirow{6}{*}{$\begin{array}{l}\text { Optimism } \\
\text { about the } \\
\text { future }\end{array}$} & & 2.60 & 10.56 & 0.00 \\
\hline Highest & & 11 & 4.80 & & \\
\hline Lowest & & & 2.48 & 11.64 & 0.00 \\
\hline Highest & & 12 & 4.96 & & \\
\hline Lowest & & & 3.32 & 5.44 & 0.00 \\
\hline Highest & & 13 & 4.76 & & \\
\hline
\end{tabular}

All t-values are significant at the (0.01)level. 
2) Reliability of the scale: The reliability of the emotional reassurance scale with its dimensions was established by the Cronbach's Alpha coefficient as shown in Table (11):

Table (11): Reliability coefficients for the emotional reassurance scale with its dimensions $(n=100)$

\begin{tabular}{|c|c|c|}
\hline Dimensions & Items No. & $\begin{array}{c}\text { Cronbach's Alpha } \\
\text { coefficient }\end{array}$ \\
\hline Emotional Maturity & 4 & $\mathbf{0 . 8 1 4}$ \\
\hline Self-satisfaction & 6 & $\mathbf{0 . 8 5 4}$ \\
\hline Optimism about the future & 3 & $\mathbf{0 . 8 4 9}$ \\
\hline Emotional reassurance scale as a whole & 13 & $\mathbf{0 . 9 0 3}$ \\
\hline
\end{tabular}

Table (11) shows that the reliability coefficients of the dimensions as well as the scale as a whole are high. indicating that the scale has a high degree of reliability.

\section{Third: Pathological Concerns Questionnaire}

The researcher reviewed studies dealt with pathological concerns. and developed a questionnaire for this variable. which included (10) items. Upon establishing the internal consistency validity of the questionnaire. one item was omitted due to the lack of significance of the value of its correlation with the overall score of the questionnaire. Therefore. the final form of the questionnaire comprises (9) items. When scoring. the existence of one negative item was taken into account.

Psychometric properties of the pathological concerns questionnaire:

1) Validity of the questionnaire: The researcher verified the validity of the pathological concerns questionnaire through:

A) Face validity (Jury member's validity): The scale was submitted to a panel of (8) jury members (professors) specialized in the field of education and psychology. in order to judge the face validity of the dimensions and items in terms of their suitability for pathological concerns. and their agreement on the items ranged between (87-91\%). 
B) Internal consistency validity: The internal consistency of the pathological concerns questionnaire was calculated as an indicator of the integrity of the scale structure. by using the Pearson correlation coefficient to exclude the items that do not correlate significantly with the overall score of the questionnaire as shown in table (12):

Finding the correlation coefficient between the items score and the overall score of the questionnaire:

The results of Table (12) indicate that all the items have a significant correlation at the level of (0.01) between the scores of the items and the total score of the questionnaire. These are the items that were agreed on. with the exception of item number (1) which was omitted due to the lack of significance of the value of its correlation with the total score of the questionnaire.

Table (12): Correlation coefficients between the item score and the total score of the questionnaire $(n=100)$

\begin{tabular}{|c|c|c|c|c|c|}
\hline $\begin{array}{l}\text { Item } \\
\text { No. }\end{array}$ & $\begin{array}{c}\text { Question } \\
\text { naire }\end{array}$ & $\begin{array}{c}\text { Item } \\
\text { Correlation } \\
\text { coefficient with } \\
\text { Questionnaire } \\
\text { overall score }\end{array}$ & $\begin{array}{l}\text { Item } \\
\text { No. }\end{array}$ & $\begin{array}{c}\text { Question } \\
\text { naire }\end{array}$ & $\begin{array}{c}\text { Item } \\
\text { Correlation } \\
\text { coefficient with } \\
\text { Questionnaire } \\
\text { overall score }\end{array}$ \\
\hline 1 & \multirow{5}{*}{$\begin{array}{l}\text { pathol } \\
\text { ogical } \\
\text { concer } \\
\text { ns }\end{array}$} & 0.055 Not Sig. & 6 & \multirow{5}{*}{$\begin{array}{l}\text { pathol } \\
\text { ogical } \\
\text { concer } \\
\text { ns }\end{array}$} & $\mathbf{0 . 7 2 5} * *$ \\
\hline 2 & & $0.391 * *$ & 7 & & $0.806 * *$ \\
\hline 3 & & $0.837 * *$ & 8 & & $0.843 * *$ \\
\hline 4 & & $0.797 *$ & 9 & & $0.737 * *$ \\
\hline 5 & & $0.677 * *$ & 10 & & $0.779 * *$ \\
\hline
\end{tabular}

C) Discriminant validity: Discriminant validity was established for each item of the pathological concerns questionnaire through calculating the highest and lowest quartiles of the piloting sample. and then the t-test was used for each item to verify that the item is able to distinguish between the highest group and the lowest group of the piloting sample on pathological concerns. Table (13) shows the results of discriminant validity:

As shown in Table (13). all the values of the t-test are significant at the level of $(0.01)$. which indicates that all 
items are able to distinguish between the lowest and highest quartiles on the pathological concerns questionnaire. and this indicates the good discriminant validity of the scale as well as its suitability for use.

Table (13): Discriminant validity of the Pathological Concerns Questionnaire $(\mathbf{n}=\mathbf{1 0 0})$

\begin{tabular}{|c|c|c|c|c|c|}
\hline Group & $\begin{array}{c}\text { Question } \\
\text { naire }\end{array}$ & $\begin{array}{c}\text { Item } \\
\text { No. }\end{array}$ & Mean & T-value & Sig. Level \\
\hline Lowest & \multirow{18}{*}{$\begin{array}{c}\text { Pathologi } \\
\text { cal } \\
\text { Concerns } \\
\text { Question } \\
\text { naire }\end{array}$} & \multirow{2}{*}{1} & 2.44 & \multirow[t]{2}{*}{5.25} & \multirow{2}{*}{0.00} \\
\hline Highest & & & 4.44 & & \\
\hline Lowest & & \multirow{2}{*}{2} & 1.48 & \multirow[t]{2}{*}{30.03} & \multirow{2}{*}{0.00} \\
\hline Highest & & & 5.00 & & \\
\hline Lowest & & \multirow{2}{*}{3} & 1.48 & \multirow[t]{2}{*}{18.22} & \multirow{2}{*}{0.00} \\
\hline Highest & & & 5.00 & & \\
\hline Lowest & & \multirow[b]{2}{*}{4} & 2.12 & \multirow[t]{2}{*}{9.83} & \multirow{2}{*}{0.00} \\
\hline Highest & & & 4.76 & & \\
\hline Lowest & & \multirow{2}{*}{5} & 2.08 & \multirow[t]{2}{*}{12.47} & \multirow{2}{*}{0.00} \\
\hline Highest & & & 4.72 & & \\
\hline Lowest & & \multirow{2}{*}{6} & 1.96 & \multirow[t]{2}{*}{12.97} & \multirow{2}{*}{0.00} \\
\hline Highest & & & 5.00 & & \\
\hline Lowest & & \multirow{2}{*}{7} & 1.68 & \multirow[t]{2}{*}{17.56} & \multirow{2}{*}{0.00} \\
\hline Highest & & & 5.00 & & \\
\hline Lowest & & \multirow{2}{*}{8} & 2.20 & \multirow[t]{2}{*}{12.96} & \multirow{2}{*}{0.00} \\
\hline Highest & & & 5.00 & & \\
\hline Lowest & & \multirow{2}{*}{9} & 1.52 & \multirow[t]{2}{*}{14.49} & \multirow{2}{*}{0.00} \\
\hline Highest & & & 4.56 & & \\
\hline
\end{tabular}

All $t$-values are significant at the $(0.01)$ level

2) Reliability of the questionnaire: The reliability of the pathological concerns questionnaire was established by using the Cronbach's Alpha coefficient. which came as shown in Table (14):

Table (14): Reliability coefficients for the pathological concerns questionnaire $(\mathbf{n}=\mathbf{1 0 0})$

\begin{tabular}{|c|c|c|}
\hline Questionnaire & Items No. & $\begin{array}{c}\text { Cronbach's Alpha } \\
\text { coefficient }\end{array}$ \\
\hline $\begin{array}{c}\text { Pathological concerns } \\
\text { questionnaire as a whole }\end{array}$ & 9 & $\mathbf{0 . 9 2 3}$ \\
\hline
\end{tabular}

Table (14) shows that the value of reliability coefficient is high. indicating that the questionnaire has a high degree of reliability. 


\section{Research findings}

Answer to the first question: What is the level of social support with its two dimensions (family and community) during Covid-19 among the Arab environment sample?

To answer this question. the researcher used the one sample t-test to compare the hypothetical mean and the true mean to identify the level of social support with its two dimensions (family and community) among the Arab environment sample. Table (15) shows the results of this question:

It is evident from Table (15) that:

- There are statistically significant differences between the real mean and the hypothetical mean of the research sample on social support with its two dimensions (family and community) in favor of the true mean. which indicates that the level of the research sample on the social support variable with its two dimensions (family and community) is high.

Table (15): Results of the level of social support with its two dimensions (family and community) among the Arab environment $(\mathbf{n}=\mathbf{1 7 3})$

\begin{tabular}{|c|c|c|c|c|c|c|}
\hline Dimension & $\begin{array}{c}\text { Hypothetic } \\
\text { al mean }\end{array}$ & $\begin{array}{c}\text { True } \\
\text { mean }\end{array}$ & $\begin{array}{c}\text { Standard } \\
\text { Deviation }\end{array}$ & T-value & Sig. & Level \\
\hline Family Support & 24 & 33.89 & 5.37 & 24.22 & 0.000 & High \\
\hline $\begin{array}{c}\text { Community } \\
\text { Support }\end{array}$ & 18 & 24.35 & 4.05 & 20.62 & $\mathbf{0 . 0 0 0}$ & High \\
\hline $\begin{array}{c}\text { Social Support as } \\
\text { a whole }\end{array}$ & 42 & 58.24 & 8.17 & 26.13 & $\mathbf{0 . 0 0 0}$ & High \\
\hline
\end{tabular}

-The hypothetical mean of the family support dimension is (24). with a (33.89) real mean. (5.37) standard deviation. and the t-value of the difference between the two means is (24.22). This value is significant at the level of (0.01) which indicates that the level of family support provided to the Arab environment sample is high. 
-The hypothetical mean of the community support dimension is (18). with a real mean (24.35). (4.05) standard deviation. and the t-value of the difference between the two means is (20.62). which is a significant value at the level of $(0.01)$. This points out a high level of community support provided to the sample of the Arab environment.

- The hypothetical mean of social support as a whole is (42). with a (58.24) real mean. (8.17) standard deviation. and the t-value of the difference between the two means is (26.13). This value is significant at the level of $(0.01)$. which means an increase in the level of social support as a whole provided to the Arab environment sample.

To answer this question. the researcher used the one sample t-test to compare the hypothetical mean and the true mean to identify the level of social support with its two dimensions (family and community) among the western environment sample. Table (16) shows the results of this question:

Table (16): Results of the level of social support with its two dimensions (family and community) among the western environment $(n=127)$

\begin{tabular}{|c|c|c|c|c|c|c|}
\hline Dimension & $\begin{array}{c}\text { Hypothetic } \\
\text { al mean }\end{array}$ & $\begin{array}{c}\text { True } \\
\text { mean }\end{array}$ & $\begin{array}{c}\text { Standard } \\
\text { Deviation }\end{array}$ & T-value & Sig. & Level \\
\hline Family Support & 24 & 29.75 & 7.69 & $\mathbf{8 . 4 2 9}$ & $\mathbf{0 . 0 0 0}$ & High \\
\hline Community Support & 18 & 23.34 & 4.91 & 12.25 & $\mathbf{0 . 0 0 0}$ & High \\
\hline $\begin{array}{c}\text { Social Support as a } \\
\text { whole }\end{array}$ & 42 & $\mathbf{5 3 . 1 0}$ & 11.82 & 10.58 & $\mathbf{0 . 0 0 0}$ & High \\
\hline
\end{tabular}

Table (16) shows the following:

-There are statistically significant differences between the real mean and the hypothetical mean of the research sample on social support with its two dimensions (family and community) in favor of the real mean. which means that the level of the research sample on the variable of social support with its two dimensions (family and community) is high. 
-The hypothetical mean of the family support dimension is (24). with a (29.75) real mean. a (7.69) standard deviation and the t-value of the difference between the two means is (8.42). This value is significant at the level of (0.01). which indicates the high level of family support provided to the sample of the western environment.

-The hypothetical mean of the community support dimension is (18). with a (23.34) real mean. a (4.91) standard deviation. and the t-value of the difference between the two means is (12.25). which is significant at the level of (0.01). This points out the high level of community support provided to the sample of the western environment.

- The hypothetical mean of social support as a whole is (42). with a (53.10) real mean. (11.82) standard deviation. and the t-value of the difference between the two means is (10.58). which is significant at the level of (0.01). This indicates the high level of social support as a whole provided to the sample of the western environment.

Answer to the third question: What is the level of emotional reassurance with its dimensions during Covid-19 among the Arab environment sample?

To answer this question. the researcher used the one sample t-test to compare the hypothetical mean and the true mean to identify the level of emotional reassurance with its dimensions among the Arab environment sample. Table (17) shows the results of this question:

Table (17): Results of the emotional reassurance level with its dimensions among the Arab sample $(n=173)$

\begin{tabular}{|c|c|c|c|c|c|c|}
\hline Dimension & $\begin{array}{c}\text { Hypothetical } \\
\text { mean }\end{array}$ & $\begin{array}{c}\text { True } \\
\text { mean }\end{array}$ & $\begin{array}{c}\text { Standard } \\
\text { Deviation }\end{array}$ & T-value & Sig. & Level \\
\hline Emotional Maturity & 12 & 15.97 & 2.88 & 18.08 & 0.000 & High \\
\hline Self-satisfaction & 18 & 24.18 & 3.88 & 20.93 & 0.000 & High \\
\hline $\begin{array}{c}\text { Optimism about the } \\
\text { future }\end{array}$ & 9 & 12.18 & 2.60 & 16.10 & 0.000 & High \\
\hline $\begin{array}{c}\text { Emotional reassurance } \\
\text { as a whole }\end{array}$ & 39 & 52.34 & 8.16 & 21.50 & $\mathbf{0 . 0 0 0}$ & High \\
\hline
\end{tabular}


It is evident from Table (17) that:

- there are statistically significant differences between the real mean and the hypothetical mean of the research sample on the factors of the emotional reassurance variable with its dimensions in favor of the true mean. which points out the high level of the research sample on the emotional reassurance variable with its dimensions.

-the hypothetical mean of the emotional maturity dimension is (12). with a (15.97) real mean. (2.88) standard deviation. and the t-value of the difference between the two means is (18.08). This value is significant at the level of (0.01). which indicates a high level of emotional maturity among the Arab environment sample.

The hypothetical mean of the self-satisfaction dimension is (18). with a (24.18) real mean. (3.88) standard deviation. and the t-value of the difference between the two means is (20.93). which is a significant value at the level of (0.01). This points out the high level of self-satisfaction among the Arab environment sample.

The hypothetical mean of the dimension of optimism about the future is (9). with a (12.18) real mean. (2.60) standard deviation. and the t-value of the difference between the two means is (16.10). This value is significant at the level of (0.01). which means a high level of optimism about the future among the Arab environment sample.

The hypothetical mean of emotional reassurance as a whole is (39). with a (52.34) real mean. (8.16) standard deviation. and the $\mathrm{t}$-value of the difference between the two means is (21.50). which is a significant value at the level of (0.01). This indicates the high level of emotional reassurance as a whole among the Arab environment sample.

Answer to the fourth question: What is the level of emotional reassurance with its dimensions during Covid-19 among the western environment sample? 
To answer this question. the researcher used the one sample t-test to compare the hypothetical mean and the true mean to identify the level of emotional reassurance with its dimensions among the western environment sample. Table (18) shows the results of this question:

Table (18): Results of the emotional reassurance level with its dimensions among the western environment sample $(n=127)$

\begin{tabular}{|c|c|c|c|c|c|c|}
\hline Dimension & $\begin{array}{c}\text { Hypothetical } \\
\text { mean }\end{array}$ & $\begin{array}{c}\text { True } \\
\text { mean }\end{array}$ & $\begin{array}{c}\text { Standard } \\
\text { Deviation }\end{array}$ & T-value & Sig. & Level \\
\hline Emotional Maturity & 12 & 14.84 & 3.81 & 8.39 & $\mathbf{0 . 0 0 0}$ & High \\
\hline Self-satisfaction & 18 & 23.03 & 4.84 & 11.69 & $\mathbf{0 . 0 0 0}$ & High \\
\hline $\begin{array}{c}\text { Optimism about the } \\
\text { future }\end{array}$ & 9 & 11.74 & 3.48 & 8.88 & 0.000 & High \\
\hline $\begin{array}{c}\text { Emotional } \\
\text { reassurance as a } \\
\text { whole }\end{array}$ & 39 & 49.62 & 10.79 & 11.08 & $\mathbf{0 . 0 0 0}$ & High \\
\hline
\end{tabular}

Table (18) shows the following:

- There are statistically significant differences between the real mean and the hypothetical mean of the research sample on the factors of the emotional reassurance variable with its dimensions in favor of the true mean. which indicates the high level of the western environment sample on the emotional reassurance variable with its dimensions.

-The hypothetical mean of the emotional maturity dimension is (12). with a (14.84) real mean. (3.81) standard deviation. and the t-value of the difference between the two means is (8.39). which is significant at the level of (0.01). This means a high level of emotional maturity among the western environment sample.

The hypothetical mean of the dimension of self-satisfaction is (18). with a (23.03) real mean. (4.84) standard deviation. and the t-value of the difference between the two means is (11.69). This value is significant at the level of (0.01). which points out the high level of self-satisfaction among the sample of the western environment.

-The hypothetical mean of the dimension of optimism about the future is (9). with a (11.74) real mean. a (3.48) standard deviation. and the t-value of the difference 
between the two means is (8.88). which is significant at the level of (0.01). This means a high level of optimism about the future among the sample of the western environment.

The hypothetical mean of emotional reassurance as a whole is (39). with a (49.62) real mean. (10.62) standard deviation. and the t-value of the difference between the two means is (11.08). This value is significant at the level of (0.01). which indicates the high level of emotional reassurance as a whole among the sample of the western environment.

Answer to the fifth question: What is the level of pathological concerns during Covid-19 among the Arab environment sample?

To answer this question. the researcher used the one sample t-test to compare the hypothetical mean and the true mean to identify the level of pathological concerns among the Arab environment sample. Table (20) shows the results of this question:

Table (19): Results of the pathological concerns level among the Arab environment sample $(n=173)$

\begin{tabular}{|c|c|c|c|c|c|c|}
\hline Dimension & $\begin{array}{c}\text { Hypothetical } \\
\text { mean }\end{array}$ & $\begin{array}{c}\text { True } \\
\text { mean }\end{array}$ & $\begin{array}{c}\text { Standard } \\
\text { Deviation }\end{array}$ & T-value & Sig. & Level \\
\hline $\begin{array}{c}\text { Pathological } \\
\text { concerns }\end{array}$ & 27 & 27.87 & 8.55 & 1.35 & $\mathbf{0 . 1 7 8}$ & Moderate \\
\hline
\end{tabular}

Table (19) shows the following:

- There are no statistically significant differences between the real mean and the hypothetical mean of the research sample on the pathological concerns. which means that the Arab environment sample has an average level of pathological concerns.

-The hypothetical mean of pathological concerns is (27). with a (27.87) real mean. a (8.55) standard deviation. and the t-value of the difference between the two means is (1.35). which is a non-statistically significant value. This means that the Arab environment sample has an average level of pathological concerns. 
Answer to the sixth question: What is the level of pathological concerns during Covid-19 among the western environment sample?

To answer this question. the researcher used the one sample t-test to compare the hypothetical mean and the true mean to identify the level of pathological concerns among the western environment sample. Table (20) shows the results of this question:

Table (20): Results of the level pathological concerns among the western environment sample $(n=127)$

\begin{tabular}{c|c|c|c|c|c|c}
\hline Dimension & $\begin{array}{c}\text { Hypothetical } \\
\text { mean }\end{array}$ & $\begin{array}{c}\text { True } \\
\text { mean }\end{array}$ & $\begin{array}{c}\text { Standard } \\
\text { Deviation }\end{array}$ & T-value & Sig. & Level \\
\hline $\begin{array}{c}\text { Pathological } \\
\text { concerns }\end{array}$ & 27 & 36.25 & 8.28 & 12.60 & 0.000 & High \\
\hline
\end{tabular}

Table (20) shows the following:

- There are statistically significant differences between the real mean and the hypothetical mean of the research sample on the pathological concerns in favor of the real mean. which means that the level of the research sample is high on the pathological concerns variable.

The hypothetical mean of pathological concerns is (27). with a (36.25) real mean. a (8.28) standard deviation. and the $\mathrm{t}$-value of the difference between the two means is (12.60). This value is significant at the level of (0.01). which means a high level of pathological concerns among the sample of the western environment.

Answer to the seventh question: Is there a statistically significant correlation between social support with its two dimensions (family and community) and emotional reassurance with its dimensions during Covid-19 among the Arab environment sample?

To answer this question. the Parson-correlation coefficient was calculated between the scores of the research sample 
on the scale of social support with its two dimensions (family and community). and their scores on the scale of emotional reassurance with its dimensions among the Arab environment sample. Table (21) shows the results of this question:

Table (21): Pearson-correlation coefficient between the research sample scores on social support scale with its two dimensions (family and community). and their scores on emotional reassurance scale with its dimensions among the Arab environment sample $(\mathbf{n}=\mathbf{1 7 3})$

\begin{tabular}{|c|c|c|c|c|c|}
\hline & & \multicolumn{4}{|c|}{ Emotional reassurance } \\
\hline \multicolumn{2}{|c|}{ Dimensions } & Emotional & $\begin{array}{c}\text { Self- } \\
\text { satisfaction }\end{array}$ & Optimism & Emotional \\
\hline \multirow{3}{*}{$\begin{array}{r}\text { Social } \\
\text { Support }\end{array}$} & Family Support & $0.350 * *$ & $0.359 * *$ & $0.305 * *$ & $0.392 * *$ \\
\hline & Community Support & $0.397 * *$ & $0.435 * *$ & $0.401 * *$ & $0.475 * *$ \\
\hline & $\begin{array}{l}\text { Social Support as a } \\
\text { whole }\end{array}$ & $0.427 * *$ & $0.452 * *$ & $0.399 * *$ & $0.493 * *$ \\
\hline
\end{tabular}

** All correlation values are significant at level $(0.01)$

Table (21) shows the following:

- There is a statistically significant positive correlation at the level (0.01) between social support with its two dimensions (family and community). and emotional reassurance with its dimensions among the Arab environment sample.

The correlation values between the two dimensions of social support and the dimensions of emotional reassurance range between $(0.305 * *-0.435 * *)$. All of these values are significant at the level of (0.01). indicating the existence of a positive direct correlation between the two dimensions of social support and the dimensions of emotional reassurance among the sample of Arab environment.

- There is a statistically significant positive correlation at the level of (0.01) between social support as a whole and emotional reassurance as a whole. whose value is $(0.493$ **) among the Arab environment sample. This indicates that the higher the degree of social support with its two 
dimensions (family and community) is. the higher the emotional reassurance with its dimensions among the Arab environment sample is.

Answer to the eighth question: Is there a statistically significant correlation between social support with its two dimensions (family and community). and emotional reassurance with its dimensions during Covid-19 among the western environment sample?

To answer this question. the Pearson-correlation coefficient was calculated between the scores of the research sample on the scale of social support with its two dimensions (family and community). and their scores on the scale of emotional reassurance with its dimensions among the western environment sample. Table (22) shows the results of this question:

Table (22): Pearson-correlation coefficient between research sample scores on social support scale with its two dimensions (family and community). and their scores on emotional reassurance scale with its dimensions among the western environment sample $(n=127)$

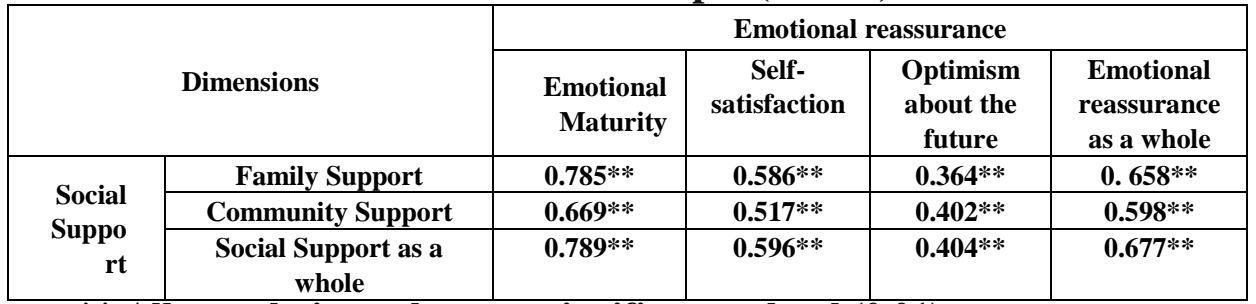

All correlation values are significant at level $(0.01)$

Table (23) shows the following:

- There is a statistically significant positive correlation at the level of (0.01) between social support with its two dimensions (family and community). and emotional reassurance with its dimensions among the western environment sample.

The correlation values between the two dimensions of social support and the dimensions of emotional reassurance 
range between $(0.364 * *-0.669 * *)$. All of these values are significant at the level of (0.01). indicating the existence of a positive direct correlation between the two dimensions of social support and the dimensions of emotional reassurance among the sample of western environment.

- There is a statistically significant positive correlation at the level of (0.01) between social support as a whole and emotional reassurance as a whole. whose value is $(0.677$ **) among the Arab environment sample. This indicates that the higher the degree of social support with its two dimensions (family and community) is. the higher the emotional reassurance with its dimensions among the western environment sample will be.

Answer to the ninth question: Is there a statistically significant correlation between social support with its two dimensions (family and community) and pathological concerns during Covid-19 among the Arab environment sample?

To answer this question. the Parson-correlation coefficient was calculated between the scores of the research sample on the scale of social support with its two dimensions (family and community). and their scores on the scale of pathological concerns among the Arab environment sample. Table (23) shows the results of this question:

Table (23): Parson-correlation coefficient between research sample scores on social support scale with its two dimensions

(family and community). and their scores on pathological concerns scale among the Arab environment sample $(n=173)$

\begin{tabular}{|c|c|c|c|}
\hline \multicolumn{2}{|c|}{ Variables } & \multicolumn{2}{c|}{ Pathological Concerns } \\
\cline { 2 - 4 } & & Correlation Value & Sig. Level \\
\hline \multirow{3}{*}{ Social Support } & Family Support & $\mathbf{0 . 0 4 5}$ & $\mathbf{0 . 5 5 1}$ \\
\cline { 2 - 4 } & Community Support & $\mathbf{- 0 . 0 6 0}$ & $\mathbf{0 . 4 3 0}$ \\
\cline { 2 - 4 } & Social Support as a whole & $\mathbf{0 . 0 0 0}$ & $\mathbf{0 . 9 9 6}$ \\
\hline
\end{tabular}

Table (23) shows that there is no statistically significant correlation between social support with its dimensions and 
the pathological concerns among the Arab environment sample.

Answer to the tenth question: Is there a statistically significant correlation between social support with its two dimensions (family and community) and pathological concerns during Covid-19 among the western environment sample?

To answer this question. the Parson-correlation coefficient was calculated between the scores of the research sample on the scale of social support with its two dimensions (family and community). and their scores on the scale of pathological concerns among the western environment sample. Table (24) shows the results of this question:

Table (24): Parson-correlation coefficient between research sample scores on social support scale with its two dimensions

(family and community). and their scores on pathological concerns scale among the western environment sample $(\mathbf{n}=127)$

\begin{tabular}{|c|c|c|c|}
\hline \multicolumn{2}{|c|}{ Variables } & \multicolumn{2}{c|}{ Pathological Concerns } \\
\cline { 3 - 4 } & & Correlation Value & Sig. Level \\
\hline \multirow{3}{*}{ Social Support } & Family Support & $\mathbf{0 . 2 5 2} * *$ & $\mathbf{0 . 0 0}$ \\
\cline { 2 - 4 } & Community Support & $\mathbf{0 . 2 8 4} * *$ & $\mathbf{0 . 0 0}$ \\
\cline { 2 - 4 } & Social Support as a whole & $\mathbf{0 . 2 8 2} * *$ & 0.00 \\
\hline
\end{tabular}

Table (24) shows that:

- There is a statistically significant positive correlation at the level of (0.01) between social support with its dimensions and the pathological concerns among the western environment sample.

- The correlation values between the two dimensions of social support and pathological concerns range between $(0.252 * *-0.284 * *)$. All of these values are at the level of (0.01). indicating the existence of a positive direct relationship between the two dimensions of social support and pathological concerns among the western environment sample.

- There is a statistically significant positive correlation at the level (0.01) between social support as a whole and 
pathological concerns valued $(0.282 * *)$ among the western environment sample.

Answer to the eleventh question: Does social support contribute to predicting emotional reassurance during Covid-19 among the Arab environment sample?

To answer this question. Enter Regression analysis was used in a model that includes emotional reassurance as a dependent variable. and the social support variable as an independent variable. where the independent variable enters the basis of its correlation with the dependent variable among the Arab environment sample. The results of the Enter Regression analysis came as shown in Table (25):

Table (25): Contribution of social support to predicting emotional reassurance among the Arab environment sample ( $n=$ 173)

\begin{tabular}{|c|c|c|c|c|c|c|c|c|c|c|}
\hline 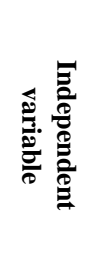 & 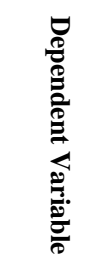 & 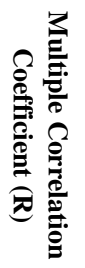 & 总高 & 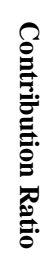 & 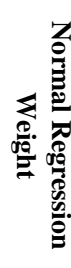 & 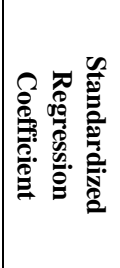 & 玨 & है & & 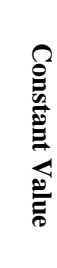 \\
\hline 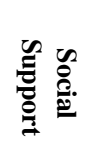 & 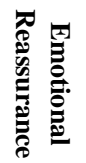 & $\begin{array}{l}\text { P. } \\
\text { t. }\end{array}$ & $\underset{i}{i}$ & 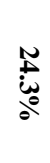 & 苦 & $\begin{array}{l}\text { to } \\
\text { t. }\end{array}$ & 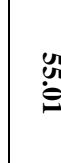 & \pm & & $\stackrel{\mathscr{N}}{\sim}$ \\
\hline
\end{tabular}

It is evident from Table (25) that the independent variable (social support) contributed to the variance of the dependent variable (emotional reassurance). The value of the multiple correlation between the two variables reached (0.493). and created a variance of (0.243) with a contribution ratio of approximately $(24.3 \%)$ of the variance of the dependent variable (emotional reassurance). Thus. it can be said that social support contributes to predicting emotional reassurance by $(24.3 \%)$ among the Arab 
environment sample. Based on the above. the regression equation indicating prediction can be as follows:

\section{Emotional reassurance $=(0.493)$ social support +23.65}

Answer to the twelfth question: Does social support contribute to predicting emotional reassurance during Covid-19 among the western environment sample?

To answer this question. Enter Regression analysis was used in a model that includes emotional reassurance as a dependent variable. and the social support variable as an independent variable. where the independent variable enters the basis of its correlation with the dependent variable among the western environment sample. The results of the Enter Regression analysis came as shown in Table (26):

Table (26): Contribution of social support to predicting emotional reassurance among the western environment sample $(n=127)$

\begin{tabular}{|c|c|c|c|c|c|c|c|c|c|c|}
\hline 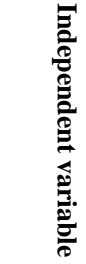 & 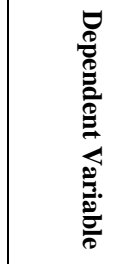 & 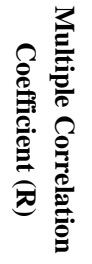 & 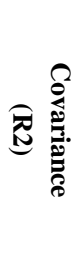 & 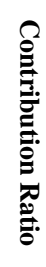 & 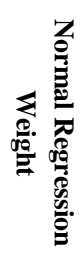 & 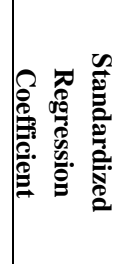 & T: & 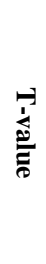 & $\frac{n}{0}$ & 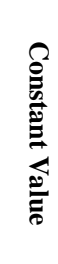 \\
\hline 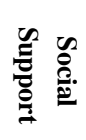 & 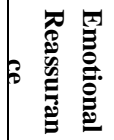 & $\dot{\overrightarrow{3}}$ & 离 & $\begin{array}{l}\text { tr } \\
\dot{\infty} \\
0 \\
0\end{array}$ & $\stackrel{\dot{\sigma}}{\infty}$ & $\dot{\hat{3}}$ & $\begin{array}{l}\overrightarrow{\bar{\prime}} \\
\dot{\alpha}\end{array}$ & $\underset{i}{\vec{\infty}}$ & ஜ் & $\overline{\grave{0}}$ \\
\hline
\end{tabular}

It is evident from Table (26) that the independent variable (social support) contributed to the variance of the dependent variable (emotional reassurance). The value of the multiple correlation between the two variables reached (0.677). and created a variance of (0.458) with a contribution ratio of approximately $(45.8 \%)$ of the variance of the dependent variable (emotional reassurance). Thus. it can be said that social support contributes to predicting 
emotional reassurance by $(45.8 \%)$ among the western environment sample. and based on the above. the regression equation indicating prediction can be as follows:

Emotional reassurance $=(0.618)$ social support +16.80

Answer to the thirteenth question: Does social support contribute to predicting pathological concerns during Covid-19 among the Arab environment sample?

To answer this question. Enter Regression analysis was used in a model that includes emotional reassurance as a dependent variable. and the social support variable as an independent variable. where the independent variable enters the basis of its correlation with the dependent variable among the western environment sample.

With reference to the ninth question. we find that there is no correlation between social support and pathological concerns among the Arab environment sample. and therefore it is not possible for social support to make a significant contribution to predicting the pathological concerns of the Arab environment sample due to the absence of any significant correlational between them.

Answer to the fourteenth question: Does social support contribute to predicting pathological concerns during Covid-19 among the western environment sample?

To answer this question. Enter Regression analysis was used in a model that includes pathological concerns as a dependent variable. and the social support as an independent variable. where the independent variable enters the basis of its correlation with the dependent variable among the western environment sample. The results of the Enter Regression analysis came as shown in Table (27): 
Table (27): Contribution of social support to predicting pathological concerns among the western environment sample $(n=127)$

\begin{tabular}{|c|c|c|c|c|c|c|c|c|c|c|}
\hline 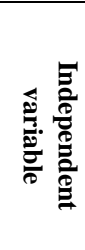 & 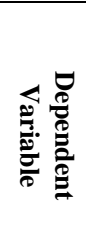 & 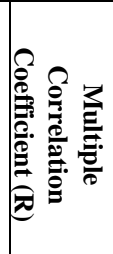 & 总商. & 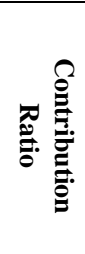 & 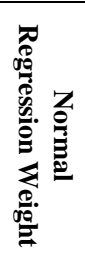 & 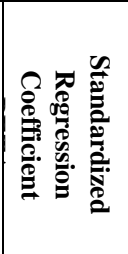 & 政 & 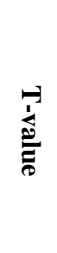 & 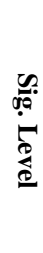 & 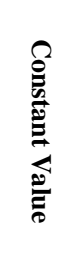 \\
\hline 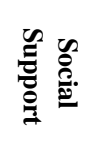 & 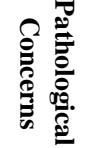 & $\underset{\substack{\text { i } \\
\text { d }}}{ }$ & 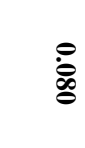 & $\stackrel{\infty}{0}$ & $\dot{\vec{b}}_{\infty}$ & 恿 & $\underset{\dot{\omega}}{\overrightarrow{0}}$ & $\underset{\text { ț }}{w}$ & 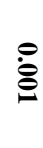 & $\begin{array}{l}\tilde{N} \\
\ddot{\sigma}\end{array}$ \\
\hline
\end{tabular}

It is evident from Table (27) that the independent variable (social support) contributed to the variance of the dependent variable (pathological concerns). The value of the multiple correlation between the two variables reached (0.282). and created a variance of (0.080) with a contribution ratio of approximately $(8.0 \%)$ of the variance of the dependent variable (pathological concerns). Thus. it can be said that social support contributes to predicting pathological concerns by $(8.0 \%)$ among the western environment sample. Based on the above. the regression equation indicating prediction can be as follows:

Pathological concerns $=(0.198)$ social support +25.76

Answer to the fifteenth question: Are there statistically significant differences with respect to the nationality variable (Arab and western environments) on social support with its two dimensions (family and community) during Covid-19?

In order to verify the significance of the differences between the mean scores of both the Arab environment sample and western environment sample on the social support with its two dimensions (family and community). the t-test "Independent Samples Test" was used to show 
the differences between the means of two independent. homogeneous groups that are not equal in number.

Table (28): Results of t-test for the significance of differences

between the mean scores of Arab and western environments samples) on social support with its two dimensions (family and community $(\mathbf{n}=\mathbf{3 0 0})$

\begin{tabular}{|c|c|c|c|c|c|c|}
\hline Sample & $\begin{array}{c}\text { Dependent } \\
\text { Variable }\end{array}$ & Mean & $\begin{array}{l}\text { Standard } \\
\text { Deviation }\end{array}$ & $\begin{array}{c}\text { T- } \\
\text { value }\end{array}$ & $\begin{array}{l}\text { Degree of } \\
\text { freedom }\end{array}$ & $\begin{array}{l}\text { Sig. } \\
\text { Level }\end{array}$ \\
\hline Arab environment sample & \multirow{2}{*}{ Family support } & 33.89 & 5.37 & \multirow[t]{2}{*}{5.48} & \multirow[t]{2}{*}{298} & \multirow[t]{2}{*}{$\mathbf{0 . 0 0}$} \\
\hline Western environment sample & & 29.75 & 7.69 & & & \\
\hline Arab environment sample & \multirow{2}{*}{$\begin{array}{c}\text { Community } \\
\text { support }\end{array}$} & 24.35 & 4.05 & \multirow[t]{2}{*}{1.94} & \multirow[t]{2}{*}{298} & \multirow[t]{2}{*}{0.53} \\
\hline Western environment sample & & 23.34 & 4.91 & & & \\
\hline Arab environment sample & \multirow{2}{*}{ Social support } & 58.24 & 8.17 & \multirow[t]{2}{*}{4.45} & \multirow[t]{2}{*}{298} & \multirow[t]{2}{*}{0.00} \\
\hline Western environment sample & & 53.10 & 11.82 & & & \\
\hline
\end{tabular}

Table (28) shows the following:

- There are statistically significant differences between the mean scores of the Arab environment sample and the western environment sample on the dimension of family support in favor of the Arab environment sample. As the mean of the Arab environment sample is (33.89) with a (5.37) standard deviation; whereas. the mean of the western environment sample is (29.75). with a (7.69) standard deviation. and the t- value is (5.48). which is significant at the (0.01) level. at (298) degrees of freedom. This means that the Arab environment sample received more family support than the western environment sample did.

- There are no statistically significant differences between the mean scores of the Arab environment sample and western environment sample on the dimension of community support. as the value of " $\mathrm{t}$ " is (1.94) and the level of significance is $(0.53)$. which is not significant.

- There are statistically significant differences between the mean scores of the Arab environment sample and western environment sample on the overall social support in favor of the Arab environment sample. As the mean of the Arab environment sample is (58.24) with a (8.17) standard 
deviation; while. the mean of the western environment sample is (53.10) with a (11.82) standard deviation. and the $\mathrm{t}$ - value is (4.45). This value is significant at the $(0.01)$ level. at (298) degrees of freedom. which means that the social support provided to the Arab environment sample is greater than that provided to the western environment sample.

Answer to the sixteenth question: Are there statistically significant differences with respect to the nationality variable (Arab environment sample and western environment sample) on emotional reassurance with its dimensions during Covid-19?

In order to verify the significance of the differences between the mean scores of both the Arab environment sample and western environment sample on emotional reassurance with its dimensions. the t-test "Independent Samples Test" was used to show the differences between the means of two independent. homogeneous groups that are not equal in number.

Table (29): Results of t-test for the significance of differences between the mean scores of Arab and western environments samples on emotional reassurance with its dimensions $(n=300)$

\begin{tabular}{|c|c|c|c|c|c|c|}
\hline Sample & $\begin{array}{c}\text { Depende } \\
\text { nt } \\
\text { Variable }\end{array}$ & Mean & $\begin{array}{l}\text { Standard } \\
\text { Deviation }\end{array}$ & $\begin{array}{c}\text { T- } \\
\text { value }\end{array}$ & $\begin{array}{c}\text { Degree } \\
\text { of } \\
\text { freedom }\end{array}$ & $\begin{array}{l}\text { Sig. } \\
\text { Level }\end{array}$ \\
\hline Arab environment sample & \multirow{2}{*}{$\begin{array}{l}\text { Emotional } \\
\text { Maturity }\end{array}$} & 15.97 & 2.88 & \multirow[t]{2}{*}{2.91} & \multirow[t]{2}{*}{298} & \multirow[t]{2}{*}{0.004} \\
\hline $\begin{array}{c}\text { Western environment } \\
\text { sample }\end{array}$ & & 14.84 & 3.81 & & & \\
\hline Arab environment sample & \multirow{2}{*}{$\begin{array}{c}\text { Self- } \\
\text { satisfaction }\end{array}$} & 24.18 & 3.88 & \multirow[t]{2}{*}{2.28} & \multirow[t]{2}{*}{298} & \multirow[t]{2}{*}{0.023} \\
\hline $\begin{array}{c}\text { Western environment } \\
\text { sample }\end{array}$ & & 23.03 & 4.84 & & & \\
\hline Arab environment sample & \multirow{2}{*}{$\begin{array}{l}\text { Optimism } \\
\text { about the } \\
\text { future }\end{array}$} & 12.18 & 2.60 & \multirow[t]{2}{*}{1.24} & \multirow[t]{2}{*}{298} & \multirow[t]{2}{*}{0.215} \\
\hline $\begin{array}{c}\text { Western environment } \\
\text { sample }\end{array}$ & & 11.74 & 3.48 & & & \\
\hline Arab environment sample & \multirow[b]{2}{*}{$\begin{array}{c}\text { Emotional } \\
\text { Reassurance }\end{array}$} & 52.34 & 8.16 & \multirow[t]{2}{*}{2.48} & \multirow[t]{2}{*}{298} & \multirow[t]{2}{*}{0.014} \\
\hline $\begin{array}{c}\text { Western environment } \\
\text { sample }\end{array}$ & & 49.62 & 10.79 & & & \\
\hline
\end{tabular}


Table (29) shows the following:

- There are statistically significant differences between the mean scores of the Arab environment sample and western environment sample on the emotional maturity dimension in favor of the Arab environment sample. as the mean of the Arab environment sample is (15.97) with a (2.88) standard deviation; whereas. the mean of the western environment sample is (14.84) with a (3.81) standard deviation. and the t-value is (2.91) which is significant at the level of (0.01) at degrees of freedom (298). This means that the level of emotional maturity among the Arab environment sample is higher than its level among the western environment sample.

- There are statistically significant differences between the mean scores of the Arab environment sample and the western environment sample on self-satisfaction in favor of the Arab environment sample as the mean of the Arab environment sample is (24.18) with a (3.88) standard deviation; while. the mean of the western environment sample is (23.03) with a (4.84) standard deviation. and the $\mathrm{t}$-value is (2.28). which is significant at the level of (0.05) at (298) degrees of freedom. This indicates that the level of self-satisfaction among the Arab environment sample is greater than its level among the sample of the western environment.

- There are no statistically significant differences between the mean scores of the Arab environment sample and western environment sample on the dimension of optimism about the future. as the t-value is (1.24) and the level of significance is $(0.215)$. which is not significant.

- There are statistically significant differences between the mean scores of the Arab environment sample and western environment sample on emotional reassurance as a whole in favor of the Arab environment sample. as the mean of the Arab environment sample is (52.34) with a (8.16) 
standard deviation; whereas. the mean of the western environment sample is (49.62) with a (10.79) standard deviation. and the t-value is (2.48). which is significant at the level of (0.05) at (298) degrees of freedom. This points out that the level of emotional reassurance among the sample of Arab environment is higher than its level among the western environment sample.

Answer to the seventeenth question: Are there statistically significant differences with respect to the nationality variable (Arab environment and western environment) on the pathological concerns during Covid19 ?

In order to verify the significance of the differences between the mean scores of both the Arab environment sample and western environment sample on pathological concerns. the t-test "Independent Samples Test" was used to show the differences between the means of two independent. homogeneous groups that are not equal in number.

Table (30): Results of t-test for the significance of differences

between the mean scores of Arab and western environments samples on pathological concerns $(n=300)$

\begin{tabular}{|c|c|c|c|c|c|c|}
\hline Sample & $\begin{array}{c}\text { Dependent } \\
\text { Variable }\end{array}$ & Mean & $\begin{array}{c}\text { Standard } \\
\text { Deviation }\end{array}$ & $\begin{array}{c}\text { T- } \\
\text { value }\end{array}$ & $\begin{array}{c}\text { Degree } \\
\text { of } \\
\text { freedom }\end{array}$ & $\begin{array}{c}\text { Sig. } \\
\text { Level }\end{array}$ \\
\hline Arab environment sample & Pathological & 27.87 & 8.55 & & & \\
\cline { 1 - 3 } $\begin{array}{c}\text { Western environment } \\
\text { sample }\end{array}$ & Concerns & 36.25 & 8.28 & $\mathbf{8 . 5 0}$ & 298 & $\mathbf{0 . 0 0}$ \\
\hline
\end{tabular}

Table (30) shows that there are statistically significant differences between the mean scores of the Arab environment sample and the western environment sample on pathological concerns in favor of the western environment sample. as the mean of the Arab environment sample is (27.87) with a (8.55) standard deviation; while. the mean the western environment sample is (36.25) with a (8.28) standard deviation. and the t-value is (5.50). which is significant at the level of (0.01) at (298) degrees of 
freedom. This means that the level of pathological concerns among the western environment sample is higher than its level among the Arab environment sample.

\section{Discussion and interpretation of findings}

- Findings revealed a high level of social support among both the Arab and western environments; however. the level of the dimension of family support among the Arab environment is higher than its level among the western environment sample. Besides. the dimension of community support is the same among the samples of the two environments. while. there are differences in favor of the Arab environment on social support as a whole. This means that the level of social support among the Arab environment is higher than its level among the western environment. This finding seems logical; as social support (especially that provided by the family) is the predominant feature of Arab societies that are proud of the existence of the family ties and strong social relations between individuals who know each other. and to a lesser extent between those who do not have direct relations. On the other hand. western environments are characterized by the independence of their members from each other to a large degree that may sometimes reach social alienation. It is known that children of western families are completely independent upon reaching the age of eighteen. and they bear the financial. psychological. scientific and practical responsibility. which makes their social support less than that of members of the Arab environment. This finding is in agreement with the study of (El-Gabali. 2006) on the high level of social support among Arab students. namely students of the College of Medicine and Health Sciences . whereas this finding is not in consistency with the study of (Abu-Talib. 2011) which revealed that the sample members have an average 
level of social support. including the dimension of family support.

- Findings showed also a high level of emotional reassurance among both the Arab and western environments. Although the levels of emotional maturity and self-satisfaction dimensions among the Arab environment are higher than their levels among the western environment. both environments showed equal levels on the dimension of optimism about the future. In addition. there are differences in favor of the Arab environment on the emotional reassurance as a whole. which means that the Arab environment sample showed a higher level of emotional reassurance than the western environment did. This is a logical finding. The high level of emotional maturity and self-satisfaction among members of the Arab environment may be due to the expansion of the environment affecting individuals (relatives. friends. neighbors and colleagues). which gave them psychological support. enhanced their selfsatisfaction. and raised their level of emotional maturity. and thus made their level of emotional reassurance higher than that of the members of the western environment. whose environment is limited to specific individuals. However. the individuals of the two environments are equal in optimism about the future due to the similarity of their thinking patterns along with the existence of cultural integration between them. which was reinforced by social networking sites before and during Covid-19.

- It was also revealed that there is an average level of pathological concerns among the Arab environment sample; whereas. the western environment sample showed a high level of pathological concerns. This is a normal result with the presence of faith in God (Allah). conviction and satisfaction with destiny and Divine Decree among members of the Arab environment more 
than among members of the western environment. Therefore. the verse " Say: "Nothing will happen to us except what Allah has decreed for us: He is our protector and on Allah let the Believers put their trust. "(AlTawbah. 51) is repeatedly said in all the ordeals and difficulties that the Arab peoples go through. in addition to the fact that the governments of Arab countries took and implemented strict health measures to prevent its spread. immediately after outbreak of the Covid-19 pandemic. which helped reduce the number of the infections and deaths. This is what alleviated the pathological concerns of the Arab peoples. As for the high level of pathological concerns among members of the western environment. the researcher attributes it to the rapid spread of the virus along with the dramatic increase in the number of infections and deaths. which led to their fear and concern for their lives and their daily routine. Thus. they took care of obtaining accurate information about this pandemic to avoid catching it. and they were certain of its severity. As consequence. their level of pathological concerns increased.

- Furthermore. there is a positive direct relationship between social support and emotional reassurance among both the Arab and western environments; however. the level of this relationship is higher among the western environment than among the Arab environment. To some extent. the researcher views that this is an acceptable result. as the more individuals feel social support from others. the more they feel reassured and safe. They are by nature prefer living in groups to living alone. and this is the prevailing pattern among the Arab environment before Covid-19. That is why reassurance was affected less among Arab environment than among the western environment. which did not undertake continuous support before the Covid-19 pandemic due to their lifestyle based 
on independence and alienation. However. when such support was provided during Covid-19. individuals' reassurance has increased significantly due to their psychological need for someone to support them and the novelty of their support experience.

This finding is consistent with the study of (Odeh. 2002) that there is a positive relationship between the psychosocial climate and emotional reassurance among the sample members. It is also in agreement with the study of (Kerns et al. 2001) on the existence of a negative correlation between feeling emotional reassurance and feeling of psychological loneliness; whoever it is not in agreement with the study of (Al-Dulaim. 2005) on the existence of a positive relationship between emotional reassurance and the feeling of psychological loneliness. as well as with the study of (Al-Jabali. 2006) on the absence of a relationship between social support and psychological stress/pressures among the sample members.

- There is no significant correlation between social support and pathological concerns among the Arab environment sample; as the Arab environment showed an average level of pathological concerns. and social support did not change this level of such concerns. This may be attributed to the fact that Covid-19 pandemic is recent in the world and is still unknown. as well as individuals do not have clear information about the nature of its transmission and spread. Besides. no vaccine has been discovered to prevent it. nor a proven treatment to cure it. This made some individuals in a state of fear of an unknown fate. and made social support with its two dimensions (family and community) useless in reducing these fears. In addition. social support during the period of the Covid-19 pandemic was through social media and not directly as was usual before Covid-19. which reduced its impact on 
reducing the pathological concerns among members of the Arab environment.

- There is a positive direct relationship between social support and pathological concerns among the western environment sample. and this indicates that the high level of social support provided for members of the western environment from family and community (as the first finding showed) has led to an increase in their pathological concerns. Despite the strangeness and illogicality of this finding. the researcher explains that members of the western environment may have known sad news about the infection or death of some of their acquaintances through the social support that they were not used to before the Covid-19 pandemic. and which were provided to them remotely and through social media. This increased their pathological concerns. They may have also witnessed the infection of a family member or friends with the virus and lived its suffering. pain and isolation. thus their pathological concerns increased. The previous two findings are not completely in line with the study of (Grassi et al. 2007) which confirmed that individuals who received less support scored higher rates on the dimensions of anxiety. depression. sadness and pathological concerns. in addition to mental illness prevailed among them compared with those who received a lot of support.

- It was revealed also that social support contributes to predicting emotional reassurance among the two environments: however. it has higher contribution among the western environment. This is a logical finding. as the social support of individuals contributes to predicting their emotional reassurance. due to its benefits on psychological. health. social and practical levels. which makes individuals feel that they are not alone. and that there are people who reassure and stand by them in light 
of the spread of this pandemic. In addition. this high level of contribution among the western environment may be due to the recent emergence of support during the spread of Covid-19. by organizing group activities through social networks. and by singing together among the members of the same neighborhood as it appeared in the news coverage. This in turn had a higher impact among the western environment than among the Arab environment.

- Social support contributes to predicting pathological concerns among the western environment; while. it did not contribute to predicting pathological concerns among the Arab environment due to the absence of any significant correlation between them. This is somewhat strange finding. since the contribution to the prediction of pathological concerns among members of the western environment through social support may mean that it was provided only to individuals already infected with this pandemic or to individuals suspected of being infected. This confirms the researcher's point of view in her interpretation of the previous findings. and in her assertion that there is no social support in the life system of the members of the western (western) environment before the Covid-19 pandemic. This made support mean infection with the pandemic. and contributes to predicting pathological concerns.

\section{Recommendations}

1) Increasing the interest of officials in all countries in the positive role of social support in alleviating the suffering of individuals in times of pandemics or in other crises. with the need to consider an alternative to direct support if it is not possible.

2) Supporting officials to design protection and prevention programs for all individuals from the pathological concerns that may spread. which will cause panic among citizens. 
which will affect their psychological and physical health. and will make them easy prey for diseases due to their weak immunity as a result of these pathological concerns.

3) Drawing attention to the importance of emotional reassurance in changing the lives of individuals for the better. and in giving them the strength to face the crises they may go through. including the infection with Covid19.

4) Urging individuals to maintain social support with close individuals. especially if they are infected with Covid-19. while taking all preventive precautions. or through social media.

5) Continuing to provide citizens with complete information about Covid-19. and spreading positive spirit in order to alleviate their pathological concerns.

6) Hospitals and psychiatric centers hold rehabilitation courses for psychologists in order to provide psychological and social support and to spread emotional reassurance to Covid-19 patients who are in quarantine.

\section{Suggestions for further research}

The researcher recommends conducting more research on the psychological effects of the Covid-19 pandemic on the Arab and western environments. such as:

1) The level and causes of family (domestic) violence during the Covid 19 pandemic.

2) A counseling program to relieve depression and anxiety in individuals during Covid-19.

3) The psychological alienation of students on scholarship to western countries during Covid 19.

4) Psychological methods to confront Covid-19 and its relationship to thought patterns.

\section{References}

Abdel-Rahman. M. A. (2014). Psychiatric and Mental Pathology: Causes. Symptoms. Diagnosis. and Treatment. Zahraa Al Sharq Library. Cairo. Egypt. 
Abu-Aisha. Zahida J. (2020). Factors of the family environment as predictors of innovative behaviors to confront social isolation during the home quarantine of Covid-19. Scientific Journal of the Faculty of Education. 36 (7). Assiut University. Egypt.

Abu-Talib. Ali B. B. (2011). Social support and its relationship to psychological security among a sample of displaced and nondisplaced students from the southern borders of Jazan region. (Unpublished Master's Thesis). Umm Al-Qura University. Kingdom of Saudi Arabia.

Al-Douri. Raya I. I. (2018). Social support among students of the College of Mass Communication at the University of Baghdad according to some variables. United States of America: Journal of the American Arab Academy for Science and Technology (AMARABAC). 9 (28). 129-142.

Al-Dulaim. Fahd B. B. (2005). Psychological reassurance and its relationship to psychological loneliness among a sample of university students. Kingdom of Saudi Arabia. King Saud University Journal of Educational Sciences and Islamic Studies. 18 (1). 329-362.

Ali. Ali A. (2000). Social support and stressful life events and their relationship to compatibility with university life among university students residing in university dorms and those residing with their families. Journal of Psychology. Egyptian General Book Authority. Cairo. Issue (53) year (4). $6-22$.

Al-Jabali. Mona M. O. (2006). Social support and its relationship to Psychological stress/ pressures among students of the College of Medicine and Health Sciences - Sana'a University. (unpublished master's thesis). Sana'a University. Yemen.

Al-Khashab. Naji A. I. (2002). The Dynamics of the Relationship between Psychosocial Support. Desire for Life and Depression among AIDS Patients: A Clinical Study. (Unpublished Ph.D. Dissertation). Faculty of Arts. Ain Shams University.

Al-Madhoun. Abdel-Karim S. (2004). Social Support as Perceived by the Physically Handicapped in Gaza Governorate and its Relation to Their Mental Health. Psychological Guidance Journal. Egypt. Issue (18). 137-174.

Al-Otaibi. Bandar B. H. (2008). Decision-making and its relationship to both self-efficacy and social support for a sample of student counselors in Taif City. (unpublished 
master's thesis). Umm Al-Qura University. College of Education. Kingdom of Saudi Arabia.

Al-Shamimary. Huda S. B. \& Barakat. Asia A. R. (2011). Level of Psychological Security (Psychological Reassurance) of the University Student in Light of Marital Status. Specialization and Academic Level. Sixteenth Annual Conference on Psychological Counseling. 645-721. Ain Shams University. Egypt.

Al-Sharif. Muhammad M. (2003). Psychological Security. 2nd Edition. Al-Andalus Green House. Jeddah. Kingdom of Saudi Arabia.

BBC News (2020). Coronavirus: Map of the Epidemic Spread and the Latest Confirmed Cases. Retrieved 7/18/2020 from https://www.bbc.com/arabic/51855397 Source: Johns Hopkins University and National Health Institutions.

Christyn. L. Dolbier. M. S. \& Mary. A. (2000). The Development and Validation of the Sense of Support Scale: Journal Behavioral Medicine. 25(4). 169-179.

Duckitt. J. H. (2000). Social Psychology and Intolerance (Series of References in Education and Psychology). translated by: Abdel Hamid. Safwat Arab Thought House. Cairo. Egypt.

Dukhan. Nabil K. \& Al-Hajjar. Basheer I. (2006). Psychological stress/pressures among students of the Islamic University and its relationship to their psychological hardness. Journal of the Islamic University (Human Studies Series). 14 (2). 369398. Palestine: Gaza

Fayed. Hussein A. (2005). Life Pressures and Perceived Control of personal and Supporting Cases as predictors of psychosomatic symptoms among a non-clinical sample. Journal of Psychological Studies. Egyptian Psychologists Association (RANEM). 15 (1). 5-53.

Gelder. M. (2012). New Oxford Textbook of Psychiatry. 3rd Edition. Oxford University Press. United Kingdom.

Grassi L.. Rasconi G.. Pedriali A. \& Corridoni A. (2007). Social Support and Psychological Distress in Primary Care Attenders. Psychother Psychosom. 69(2). 95-100

Harel. Y. Sheshtman. Z. \& Cutrona. C. (2012). Exploration of Support

Behavior in Counseling Groups with Counseling Trainees. The Journal for Specialists in Group Work. 37 (3). 202-217 Holy Quran. 
Ibrahim. Ibrahim E. (2010). Internet addiction and its relationship to psychological loneliness and psychological reassurance among students of Khalid University in Saudi Arabia in light of some demographic variables. Egypt. Journal of Psychological Studies. Egyptian Psychologist Association (RANM). 20 (3). 437-464.

Kerns k.. Aspelmeier J.. Gentzler. A. \& Grabill. C. (2001). ParentChild Attachment and Monitoring in Middle. Childhood. Journal of Family Psychology. 15(1). 69-81.

Odeh. Fatima Y. I. (2002). The Psychosocial Climate and Its Relation to the Emotional Reassurance and Ego Power of Female Students of the Islamic University of Gaza. (Unpublished Master Thesis). Islamic University. Palestine. Gaza

Othman. Ahmed A. I. (2001). Spousal social support and its relationship to happiness and compatibility with university life among married university students. Journal of the College of Education in Zagazig. Issue (37). 143-195. Egypt.

Radwan. Shaaban J. (2001). The relationship between social support and all aspects of depression. self-esteem and life satisfaction. Journal of Psychology. Issue (72). 58-109. Egypt

Saad. Asaad N. (2001). The Effectiveness of a Behavioral Therapy Program for Working with Groups to Reduce Some Common pathological concerns among primary school girls in late childhood. (Unpublished PhD thesis). Ain Shams University. Egypt.

Sahih Al-Bukhari. No. (6011). and Sahih Muslim. No. (2586).

Shuwaikh. Hanaa A. (2007). Methods of relieving psychological stress/pressure resulting from carcinoid tumors with applications on Cancerous bladder tumors Cases. 1st Edition. Etrac For Printing. Publishing \& Distribution. Cairo. Egypt.

Taylor. S. (2011). Social Support: A Review. In M.S. Friedman. New York: Oxford University Press. 189-214

Taylor. Shelley (2016). Health Psychology. 5th Edition. Translated by: Brick. Darwish and Taaima \& Shaker. Jordan: Hamed House for Publishing and Distribution.

Yusoff Y. M. (2012). Self-Efficacy. Perceived Social Support and Psychological Adjustment in International Undergraduate Students in aPublic Higher Education Institution in Malaysia. Journal of Studies in International Education. 16(4). 353-371.

\section{$* * *$}

